\title{
Nepomuceno e Brahms: A Questão da Influência Revisitada
}

João Vicente Vidal'

\section{Resumo}

O estudo busca aprofundar a compreensão das frequentemente apontadas relações da obra de Alberto Nepomuceno com a música germânica do final do séc. XIX, oferecendo para esse fim uma reavaliação da questão da influência de Brahms, e aqui especificamente no contexto de seus anos de formação em Berlim, sobre seu estilo musical. A fim de contemplar tanto a consideração do contexto histórico do problema quanto uma apreciação das composições de Nepomuceno orientada a uma análise estilística, é proposto o emprego dos conceitos de 'recepção' e de 'intertextualidade'. Tal abordagem, esperamos, poderá levar-nos a uma melhor compreensão do legado de Nepomuceno, bem como a uma definição mais precisa de seu lugar no panorama da música brasileira da virada do século.

Palavras-chave: Alberto Nepomuceno; música brasileira; música germânica.

\footnotetext{
${ }^{1}$ Este artigo procura expor conclusões preliminares de nossa pesquisa em andamento no âmbito do programa de doutorado em Musicologia da Escola de Comunicações e Artes da Universidade de São Paulo em conjunto com o Musikwissenschaftlichés Seminar da Humboldt-Universität zu Berlin, sob orientação e co-orientação dos Professores Marcos Branda Lacerda e Hermann Danuser. Cordiais agradecimentos são devidos a ambos e ao programa conjunto de bolsas de estudos DAAD/Capes/CNPq, que possibilitaram um período de estudos relativamente longo na referida universidade em Berlim, e, ainda, a Norton Dudeque e Rodolfo Coelho de Souza, o primeiro pelo gentil convite a participar do presente volume, o segundo pelo proveitoso intercâmbio de ideias no âmbito de uma disciplina sua na Universidade de São Paulo, no primeiro semestre de 2008.

João Vicente Vidal possui graduação (1999) e Mestrado (2002) em Música pela Universidade Federal do Rio de Janeiro (UFRJ). Desde 2004 é professor da mesma instituição. É doutorando em Musicologia Histórica pelo programa de pós-graduação em música da Universidade de São Paulo e Humboldt-Universität zu Berlin.
} 


\section{Introdução}

Uma das mais recentes tendências da pesquisa sobre Alberto Nepomuceno, visando uma reavaliação de sua música e posição no panorama geral da música brasileira, é a busca por uma compreensão mais profunda das relações de sua obra com as direções estilísticas existentes no universo da música germânica do final do séc. XIX, especialmente no contexto de seus anos de formação em Berlim (1890-1894). Num ensaio hoje já bastante conhecido, Norton Dudeque destacou a importância de seu contato com o 'academicismo' germânico e o reflexo deste em sua orientação estilística, por um lado, e o papel dominante desempenhado por Brahms no campo de relações estabelecido por Nepomuceno com suas fontes musicais europeias, por outro (Dudeque, 2005, p. 211-232). Dudeque se remeteu à teoria musical circulante na Berlim dos anos de formação de Nepomuceno e ao conceito de schoenberguiano de 'variação progressiva' para analisar o primeiro movimento do Quarteto de Cordas n. 3, e sugerir daí ter sido a música de Beethoven e Brahms, mais que a de Wagner, a principal fonte do compositor (Dudeque, p. 228). Sua proposta, "fazer um paralelo entre as instruções contidas no Tratado de Composição [Die Lehre von der musikalischen Komposition] de [Adolf Bernhard] Marx e a música de Nepomuceno. [...] [e,] de outro ponto de vista, [relacioná-la com] o conceito schoenberguiano de variação progressiva [...] para a identificação das ideias que [Heinrich von] Herzogenberg [um dos professores de composição de Nepomuceno em Berlim] pode ter apresentado para Nepomuceno" (Dudeque, p. 217), faz de seu trabalho, portanto, uma investigação teórico-estilística da música do brasileiro desde a perspectiva de duas sistematizações da música do Classicismo germânico (isto é, alemão e vienense): a primeira, de Marx, empreendida por volta do meio do século e baseando-se principalmente na música de Beethoven (e constituindo, para Nepomuceno, o que poderíamos chamar de teoria musical 'de época', no sentido de uma teoria que ele teria conhecido); a segunda, de Schoenberg, elaborada na primeira metade do séc. XX principalmente a partir da música de Brahms. 
Sem perder de vista as importantes e pioneiras indicações de Dudeque, enveredamos por um caminho diverso (e todavia paralelo) ao seu, buscando não tanto a identificação do substrato teórico das composições de Nepomuceno, bem como o de seus mestres e modelos, uma tarefa claramente afim ao viés sistemático da disciplina musicológica, quanto a identificação das referências e relações (referidas aqui de forma ampla como 'de intertextualidade') encontráveis nas próprias obras musicais de todos esses compositores, uma proposta concebida a partir de uma perspectiva histórica e fundamentada em nossa investigação acerca de seu contato com esse repertório em seus anos de estudo em Berlim. Apesar da proximidade entre o estilo musical de Nepomuceno e aquele do que já foi chamado de 'tradição de Brahms' já ter sido frequentemente mencionada na literatura sobre o compositor, podemos dizer que apenas poucos estudos, como o já mencionado, se dedicaram até hoje mais detidamente a esta relação, ou a como Nepomuceno concebeu algumas de suas obras especificamente a partir de modelos brahmsianos. Consoante a tendência acima enunciada, e por força das necessidades naturais de delimitação de qualquer estudo da obra de Nepomuceno, que se não é vasta como a de compositores como Villa-Lobos, 90 também não pode ser classificada como diminuta, uma vez que abarca uma enorme gama de gêneros instrumentais e vocais, focamos nossa pesquisa na sua música instrumental, com especial ênfase naquela dos anos Berlim.

A música instrumental de Nepomuceno, assim como algumas obras dos anos imediatamente posteriores, sugere um estilo musical informado por aquela que é uma das principais linhas de força da música alemã da segunda metade do séc. XIX: o assim chamado 'Classicismo romântico', voltado sobretudo ao cultivo e afirmação das formas tradicionais da música instrumental do Classicismo vienense (e em cujo horizonte Brahms se destaca como um de seus mais importantes representantes). No entanto parte desse conjunto de composições revela também a influência do 'nacionalismo romântico' desenvolvido principalmente em países da esfera de influência imediata da Alemanha (o que nos permite descrever essa tendência estilística confortavelmente como uma derivação da tradição da música instrumental germânica). Naturalmente essa constatação não deve surpreender. Sabidamente o conjunto da obra de Nepomuceno reflete não apenas essas, mas 
também quase todas as tendências composicionais de sua época e dos diferentes ambientes com os quais o compositor travou contato. Por essa razão, Nepomuceno foi em mais de uma ocasião apropriadamente descrito como um 'eclético'.

O enunciado do ecletismo, no entanto, contém mais o diagnóstico do problema que sua decifração. Para elucidar aspectos estilísticos pontuais na obra do compositor (no caso presente sua relação com a 'tradição de Brahms' do fim do século, um aspecto que, sendo apenas um entre muitos, nos parece por diversas razões essencial para a compreensão de suas realizações posteriores), e em todo caso para fazê-lo em qualquer campo da música brasileira do séc. XIX, onde tanto fortes relações com a música europeia quanto o já referido 'ecletismo' recorrem como características definidoras, julgamos necessário o emprego de instrumentos teóricos que viabilizem uma análise estilística em que um elemento essencial desse tipo de análise - o contexto cultural, histórico e mesmo geográfico - frequentemente não está dado claramente. Por oferecerem subsídios para uma abordagem baseada na dupla raiz de história 'contextual' e 'composicional', acreditamos que dois desses instrumentos podem ser identificados nos conceitos (provenientes da crítica literária) de 'recepção' e de 'intertextualidade'. Tal abordagem, nos parece, pode fazer jus tanto ao estudo do compositor em seu tempo, isto é, em suas relações na esfera histórica, quanto àquele da estrutura da obra em suas relações com as estruturas de outras obras. As considerações que seguem procuram, portanto, abranger tanto aspectos contextuais quanto composicionais do período e da música nos quais se concentra nossa pesquisa, abordando também (algo intersticialmente) algumas das mais prementes questões historiográficas e metodológicas suscitadas pelo tema. Ao fim tratamos, como um breve exemplo do tipo de apreciação da música que se pode fazer a partir desses conceitos, das pouco comentadas peças para piano do compositor, suas três Folhas d'Álbum de c. 1891. 


\section{A Música Brasileira do Séc. XIX e Nepomuceno: Perspectivas Historiográficas}

“A Geografia [...] rivaliza cada vez mais com a história como um tipo de pré-disciplina [Ur-discipline] da musicologia” (Samson, 2005, p. 6), notou há alguns anos Samson. De fato, a ideia de uma 'geografia cultural' tornou-se um tema central da musicologia contemporânea, e um tema que direcionou fortemente sua atenção, nas últimas décadas, tanto para o repertório musical de culturas que estiveram no passado para além de uma influência cultural direta ou fora da esfera de dominação das potências coloniais europeias, quanto para a música de países que podem ser descritos como antigas 'periferias culturais' da Europa. Muito embora se possa perceber nesse desenvolvimento o impacto dos estudos pós-coloniais e antropológicos do séc. XX, se expressa nele por outro lado uma tendência da prática musical e da musicologia europeia contemporâneas: a tentativa de redescobrir a música de seus próprios compositores 'esquecidos', para com isso expandir o repertório tradicional e canonizado.

Inegavelmente o estudo de grande parte da música artística do Brasil do

92 séc. XIX poderá ser compreendido como um exame de tal geografia cultural, sempre e na medida de em que se buscar aprofundar a compreensão dessa música com o interesse voltado às relações entre Brasil e Europa. E ainda que o estudo da música de um país 'dos trópicos' e suas relações com a arte e cultura europeias corra o risco de ser hoje tomado (principalmente fora do país) ou como exótico - já que se pensa, quando o assunto é a música brasileira, imediatamente em suas (conhecidas ou presumidas) características 'típicas', sejam elas elementos musicais populares ou folclóricos, sejam elas criações livres inspiradas nesses elementos, e não em seus aspectos 'cosmopolitas' - ou como uma proposta perigosamente eurocentrista - numa época em que tal postura parece ser combatida todas as forças -, o caso da música brasileira do séc. XIX é um onde não se apresentam soluções fáceis. Se por um lado tais 'características musicais tipicamente brasileiras' não haviam sido amplamente absorvidas na esfera da música artística, por outro deve-se tomar como eurocentrista não a pesquisa, mas 
a própria sociedade brasileira da época, em geral, e as práticas da alta cultura local, em particular.

À luz dessa avaliação, delineia-se quase naturalmente como um primeiro núcleo de questões e problemas da música brasileira do séc. XIX o tema geral do seu suposto epigonismo, isto é, de sua adoção de estilos musicais europeus. Visando mais especificamente o posicionamento de Nepomuceno em relação à arte e cultura alemãs (e especialmente seus anos de formação em Berlim e composições período), chegamos a um segundo núcleo de questões, intimamente interligado com o primeiro: o fenômeno do entusiasmo pela cultura germânica na vida intelectual brasileira do final do século, um fenômeno que tomou a forma de um movimento discutido frequentemente na história intelectual brasileira como 'germanismo', e cujo efeito na música local, apesar de importante, recebeu até hoje pouca atenção. Compondo, juntos, um ponto de partida para o estudo da obra de Nepomuceno, esses dois núcleos de questões nos oferecem também oportunidade de refletir sobre os conceitos e procedimentos dos quais a pesquisa sobre a música do séc. XIX em geral tem até hoje se valido, para a apreciação do vasto repertório de obras musicais do período.

\section{A Questão do 'Epigonismo' na Pesquisa da Música Brasileira do Séc. XIX}

A música brasileira do séc. XIX, e principalmente a de sua segunda metade, foi até muito pouco tempo uma área relativamente negligenciada pela musicologia do país, se comparada com os esforços dedicados nas últimas décadas às duas grandes frentes da música do período colonial e da música do séc. XX posterior à Semana de Arte Moderna de 1922. O desinteresse parece se explicar, ao menos em parte, pela institucionalização da musicologia no país no período imediatamente anterior à Segunda Guerra Mundial, quando se desenvolvia com forte impulso a crítica modernista cujas ortodoxas teses nacionalistas se opunham às escolas românticas do período anterior, por um lado, e pouco antes da descoberta do rico passado musical do período colonial brasileiro, por outro. Se o 
primeiro fator transformou em 'problema' a proveniência europeia da linguagem musical de grande parcela da música brasileira do séc. XIX, o segundo obteve sucesso ao atrair a atenção de um enorme número de pesquisadores; juntos, ambos colaboraram para a disseminação de uma rejeição generalizada ao Romantismo brasileiro e seus vínculos estilísticos e estéticos com a Europa. Para além das circunstâncias locais da pesquisa musical brasileira do séc. $X X$, é de se observar, naquele momento, atitude semelhante em relação ao séc. XIX também em escala internacional. Como Finscher sugeriu, "a música do século XIX representou, no período entre-guerras, e mesmo após 1945, um tabu para certo círculo de músicos e pesquisadores, assim como para o público ligado a esse círculo" (Finscher, 1976, p. 6). Poderíamos supor que essa desconfiança da música romântica e romântica tardia na Europa foi compartilhada pela crítica nacional na primeira metade do séc. XX?

Mário de Andrade, tomando emprestada expressão de Manoel Bandeira, definiu a música do séc. XIX, de Pe. José Maurício a Carlos Gomes e Leopoldo Miguéz, como sendo de "um ruim que não é ruim propriamente [...] [mas] um ruim esquisito" (Andrade, 1972, p. 17). A europeicidade da cultura brasileira do 94 período sempre foi lembrada por Andrade como seu aspecto negativo, de onde provém a concorde sua crença de que "antes do advento do Modernismo nos anos de 1920 a cultura brasileira - e, por associação, a música brasileira - não existia como tal". ${ }^{2}$ Já críticos de países europeus, que ao longo do séc. XIX haviam descoberto (não menos que criado) suas próprias 'consciências nacionais', parecem ter esperado encontrar um sentimento nacional semelhante ao que possuíam também na música da mesma época de países como o Brasil, muito embora no contexto da música brasileira do séc. XIX mal existisse, como (recorrentemente) notado por Mário de Andrade, o que se chama hoje de 'identidade nacional'. Um exemplo é a seguinte passagem do artigo "Brésil"

\footnotetext{
${ }^{2}$ Apud Magaldi, 2004, p. $x$ (itálicos nossos). O ponto de vista de Mário de Andrade deriva, porém, de sua convicção de que só poderia ser chamada de brasileira uma arte que refletisse uma unidade racial e cultural que ele desconhecia no Brasil do séc. XIX. Como comentou Magaldi, "[...] Andrade sugere, no Ensaio [sobre a Música Brasileira], que não havia brasileiros no séc. XIX, apenas índios, negros e europeus sem unidade cultural (e racial)".
} 
(1920) de Darius Milhaud, que viveu na capital Rio de Janeiro entre 1916 e 1918 como attaché da embaixada francesa no país:

É de se lamentar que todas as obras dos compositores brasileiros, desde as sinfônicas ou de câmara dos senhores Nepomuceno e Oswald, até as sonatas impressionistas do Sr. [Oswaldo] Guerra ou as obras orquestrais do Sr. VillaLobos (um jovem temperamento robusto, cheio de ousadias), sejam um reflexo das diversas fases que se sucederam na Europa, de Brahms a Debussy, e que o elemento nacional não se tenha revelado de uma maneira mais vivaz e mais original [...] Quando um tema popular ou o ritmo de uma dança é utilizado em uma obra, este elemento local é deformado porque o autor o vê através das lentes de Wagner ou de Saint-Saëns, se ele tem sessenta anos, ou através das de Debussy, se ele tem apenas trinta (Milhaud, 1920, p. 61). ${ }^{3}$

Muito embora, como indicado em pesquisas recentes, ${ }^{4}$ o movimento modernista tenha sido ele próprio alimentado por uma importação de ideias muito semelhante à apontada na prática dos compositores brasileiros do séc. XIX o que revela, e não sem alguma dose de ironia, uma forma de influência similar àquela que esse o movimento criticava com veemência na arte brasileira do século anterior em geral $^{5}$-, sua crítica cristalizou na musicologia nacional uma avaliação negativa da música brasileira anterior a Villa-Lobos (Cf. Monteiro, 2000). Com a centralização do debate em torno a questão do nacionalismo na música, a

\footnotetext{
${ }^{3}$ Em 1917, contudo, Milhaud se expressava em correspondência a Nepomuceno em termos bastante diversos, que revelam sua atitude um tanto vacilante - ou meramente pragmática, dado que o francês parecia então desejar estabelecer relacionamento com os mais proeminentes compositores locais - em relação à música abordada no artigo posterior de 1920: "Caro Mestre, eu tenho a vos dizer de toda a alegria que tive ontem ao ouvir vosso belo Trio. O Sr. Henrique Oswald me havia alertado da repetição do seu Trio e do vosso no Instituto e eu me alegrei ontem por ouvir estas duas obras nas quais se delineam tão distintamente os temperamentos tão diferentes dos dois maiores compositores do Brasil. Eu reencontrei na audição de ontem todas as qualidades de vigor, de grandeza, de profundidade do sentimento que eu havia sentido em vosso Trio na ocasião em que o Sr. tão amavelmente nos apresentou a ele ao piano. Eu espero que o Sr. o publique em breve, para que eu possa levá-lo à Europa e mostrá-lo a meus amigos em Paris assim que retornar [...] Eu vos exorto, caro mestre, a acreditar em minha sincera admiração e verdadeira simpatia [...]. Milhaud" (Alvim Corrêa, 1996, p. 32, itálicos de Milhaud).

${ }^{4} \mathrm{~A}$ influência europeia no desenvolvimento do modernismo musical brasileiro foi estudada, entre outros, por Manoel Aranha Corrêa do Lago (2005).

5 Essa contradição não pode ser explicada senão através da leitura de que para os modernistas a importação de estilos e a importação de ideias seriam modalidades diversas (senão opostas) de assimilação cultural, das quais a última favoreceria o desenvolvimento de uma expressão artística original e autêntica. Como veremos, esta noção permeava o discurso sobre a questão da influência europeia já no último quarto do séc. XIX, na discussão em torno das influências francesa e alemã desenvolvida no âmbito do 'germanismo'.
} 
produção do séc. XIX passou a ser descrita como 'epigonal' (de ' Tíyovoi': o nascido depois, herdeiro, descendente ou sucessor). No entanto a expressão 'epigonismo', neutra em si, tem sido empregada, desde sua origem no romance Die Epigonen (1836) de Karl Immermann, de forma claramente pejorativa (e ainda mais em relação a todas as artes da era da originalidade e do individualismo), na medida em que com ela se procura denotar uma atividade criativa essencialmente imitatória. Mas se para seus críticos estava claro que essa música constituiria uma imitação da música europeia, o que exatamente ela imitava não estava. A primeira recepção da música desta época mostra que, nesse ponto, uma grande confusão imperou. Assim relatava Felix Welcker dois concertos da 'Exposição Universal e Internacional' de Bruxelas em 1910:

[...] de quatro concertos brasileiros [programados] sob a direção de Nepomuceno, o diretor do Conservatório do Rio de Janeiro, dois aconteceram e trouxeram uma agradável demonstração dos esforços dos brasileiros. Tomaram parte nomes como Nepomuceno, Gomes, Miguez e Oswald, cujas obras movem-se segundo o gosto italiano e francês (Welcker, 1910, p. 381-383).

E em 1915 Walter Niemann narrava, por sua vez, uma viagem sua ao Brasil:

[...] nos anos de 80 e 90 do século passado Schumann deitou raízes fortes no Brasil. [...] Um Allegro appassionato póstumo [de Alexandre Levy] mostra o mesmo quadro. A obra de um romântico alemão! [...] um Noturno em mi bemol menor [sic] de Nepomuceno, o diretor do Conservatório do Rio de Janeiro formado na Berliner Hochschule [sic]. O correlato brasileiro para a Serenade op. 3 do russo Rachmaninoff [...] eleva-se impetuosamente na seção central chopiniana, através de um recitativo lisztiano dissolve-se no distante modo maior e exaure-se flutuando no infinito ... Que a moderna música romântica para piano de Chopin, Schumann e Grieg determinou os mais decisivos estímulos confirma também Barrozo Netto. [...] $\mathrm{O}$ mais refinado talento pianístico entre os jovens brasileiros, Henry [sic] Oswald, Ihe segue nisso [...] O pequeno Preludio do op. 3 sugere Brahms, o Scherzo transplanta as aparições de fadas de Mendelssohn para a Sierra [sic] brasileira, os dois Improvisos assumem o tom fantástico e cheio de humor de Schumann. Especialmente Schumann, e depois dele também Chopin e Grieg, são, assim como para todos os habitantes do sul, também os deuses de Oswald (Niemann, 1915, p. 271-273).

Segundo o gosto italiano e francês, mas ao mesmo tempo também dependente da música de Schumann, Rachmaninoff, Chopin, Liszt e Grieg (e 
segundo Milhaud também da de Brahms, Debussy, Wagner e Saint-Saëns)! (Deixando de lado descrição posterior do Harvard Dictionary of Music, segundo a qual Nepomuceno, “com técnicas emprestadas de Wagner, Puccini e Debussy, [...] escreveu canções, peças para piano e uma Série Brasileira para orquestra de um espírito decididamente brasileiro (Orrego-Salas, 1969, p. 111a). Assim como ocorre na recepção da música brasileira do séc. XIX na Europa (tomando aqui, como amostragem, apreciações oriundas de dois dos seus mais proeminentes países, França e Alemanha), a crítica brasileira do final do séc. XIX e começo do XX caracteriza-se pela ênfase em similaridades e supostas influências, sem que tais observações, no entanto, sejam fundamentadas analiticamente (como certa crítica de Oscar Guanabarino, segundo a qual Nepomuceno teria plagiado Schubert em uma de suas canções (apud Pereira, 2007, p. 115). Além disso, percebe-se quase nenhum interesse pelas características únicas e pelos desvios da norma, que podem ser muito mais reveladores que as similaridades. O quê e de quem esses compositores tomaram emprestado? Essas perguntas nunca foram suficientemente examinadas ou esclarecidas, uma atitude em relação ao séc. XIX limitou fortemente a pesquisa da música do próprio séc. $X X$, na medida em que a sua 'pré-história' permaneceu praticamente desconhecida.

Ocorre, por outro lado, que a maior parte dos estudos da música brasileira do séc. XIX tomaram a forma de esboços concebidos no âmbito de ensaios panorâmicos, de narrativas amplas da história da música no Brasil, ${ }^{6}$ que não puderam, por força de suas delimitações via de regra ambiciosas e estilo frequentemente mais literário que acadêmico, fazer uso de toda a gama de evidências documentais e métodos de análise musical (reconhecidos hoje como imprescindíveis à tarefa) para promover uma avaliação objetiva dessa música. 0 foco dessas fontes recaiu, ao contrário, principalmente em informações biográficas

${ }^{6}$ Estas narrativas compõem hoje o conjunto de fontes 'clássicas' do estudo da música brasileira: Melo, Guilherme de: A Música no Brasil desde os Tempos Coloniais até o Primeiro Decênio da República, 1908; Cernicchiaro, Vicenzo: Storia della Música nel Brasile, dai Tempi Coloniale sino ai Nostri Giorni (1549-1925), 1926; Almeida, Renato: História da Música Brasileira, 1942 (1926) e Compêndio de História da Música Brasileira, 1958 (1948); Andrade, Mario de: Ensaio sobre a Música Brasileira, 1928 e Música, Doce Música, 1934; Corrêa de Azevedo, Luiz H.: Relação das Óperas de Autores Brasileiros, 1938, Música e Músicos do Brasil, 1950, e 150 Anos de Música no Brasil (1800-1950), 1956; Kiefer, Bruno: História da Música no Brasil, 1976; e Mariz, Vasco: História da Música no Brasil, 1981. 
e testemunhos (por vezes não mais que anedóticos) de primeira mão. Assim, o valor dessa literatura deve ser reconhecido levando-se em consideração o quadro maior do crônico problema de fontes na pesquisa sobre a história da música no Brasil, e a despeito das discrepâncias decorrentes de seus esforços isolados e individuais (especialmente no que se refere às periodizações propostas). Quantos aos estudos de uma geração posterior (Béhague, 1971, e 1979), pode-se dizer que se introduziram maior perícia no tratamento do texto musical e delimitações de estudo mais propícias ao estudo detalhado de cada um de seus problemas, por outro lado mantiveram a atitude prévia de pouca atenção à fundamentação documental do trabalho, bem como o caráter parti pris das discussões em torno do nacionalismo na música brasileira.

Com a possível exceção dos estudos de Guilherme de Melo e Vicenzo Cernicchiaro, podemos observar nesta literatura o obscurecimento da compreensão do complexo ímpeto que motivou a apropriação da cultura europeia no Brasil do séc. XIX, um dos principais efeitos da ideologia modernista na musicologia brasileira. Ainda que a literatura de inspiração modernista não pudesse negar de todo o valor de ícones nacionais como 98 Gomes, Nepomuceno e Oswald, o foco nas tradições musicais europeias foi deliberadamente limitado, como apontou Cristina Magaldi, aos casos em que se pensasse haver ocorrido algum tipo de "fertilização mútua [crossfertilization]" (Magaldi, 2004, p. xv), entre o elemento europeu e o elemento local; obras em que não se verificasse tais relações foram consideradas, consequentemente, imitações empobrecidas - 'acadêmicas' - da música europeia. E de fato o Modernismo se definiu, em grande medida, em oposição ao academicismo enxergado no período anterior, fazendo com que os compositores românticos brasileiros fossem classificados como imitadores, precursores (do processo de nacionalização da música brasileira) ou ainda, paradoxalmente, como ambos.

Muitos anos após o apogeu do movimento modernista, Gerard Béhague reafirmou (ainda que com certa condescendência) essa posição, na assertiva de que "os compositores deste período de transição (c. 1880-1920) continuaram a ser essencialmente acadêmicos; seus ideais eram amplamente direcionados à 
música europeia romântica e pós-romântica, incluindo a influência universal de Wagner [...] Embora suas atitudes em relação à música brasileira 'genuína' que emergiu por volta da mesma época não fossem negativas" (Béhague, 1971, p. 9). Assim, o academicismo apontado nos compositores oitocentistas passou a ser contrastado diretamente com o surgimento de uma música brasileira 'genuína', e portanto com a ideia do nacionalismo na música brasileira, o principal foco de atenção do movimento modernista (ao menos depois de 1922). Resumidamente, a agenda do Modernismo relegou toda iniciativa pouco ou não comprometida com o desenvolvimento de uma música 'genuinamente' brasileira (o que seria genuíno ou não foi naturalmente definido muito tempo depois, e pelos próprios modernistas) às categorias da decadência - dos 'epígonos' e 'acadêmicos', ou da insipiência - dos 'precursores'. Mais que julgamentos estéticos, o modernismo disparou julgamentos ideológicos (isto é, julgamentos em que a perspectiva do observador é dogmaticamente tomada como a 'verdade') contra a música brasileira do séc. XIX, fundados em suas ideias sobre o que seria uma 'expressão autêntica' da nacionalidade brasileira na música. Com a questão sobre a presença ou ausência de um nacionalismo musical dominando o debate sobre a música oitocentista no séc. $X X$, estabeleceu-se a noção de que essa discussão foi também um aspecto dominante do discurso geral sobre essa música em seu próprio tempo, e não um de seus diversos tópicos. Assim aspectos como as relações entre música e literatura e os embates de tradição e inovação - temas da ordem do dia no séc. XIX, e não apenas na Europa, como também no Brasil - foram preteridos nos estudos do séc. XX, devido talvez ao mais difícil reconhecimento de seus reflexos na 'fisionomia' da obra musical, em comparação com as características imediatamente reconhecíveis de todo e qualquer 'nacionalismo musical'. 


\section{O 'Germanismo' na História Intelectual do Brasil e seu Impacto na Música}

Ao lado do problema geral da adoção de estilos musicais europeus por compositores brasileiros ao longo do séc. XIX, e como uma temática que colabora diretamente com uma aproximação mais apurada da obra de Nepomuceno, coloca-se a questão mais ampla do impacto da cultura germânica - o fenômeno do 'germanismo' - na história intelectual do brasileiro e seus reflexos na música do país. Temos, então, como complemento à indagação sobre o quê e de quem aqueles compositores tomaram 'emprestado', a pergunta sobre por que alguns se voltaram para fontes italianas (como Gomes), outros para fontes alemães (Nepomuceno e Miguéz) e outros, ainda, para as francesas (Oswald e Braga, entre outros). Que lógica residiria nas opções estilísticas feitas por cada compositor? Como as realizações artísticas de cada um se relacionam não apenas com o contexto geral do Brasil do séc. XIX (e, em muitos casos, também do início do séc. $X X)$, mas também com os contextos particulares das destinações de estudos desses compositores na Europa, constitui, de fato, um campo ainda a ser explorado pela pesquisa musical brasileira (vide Volpe, 1995).

A música brasileira, durante o séc. XVIII quase totalmente dependente das formas e gêneros do pré-Classicismo austro-germânico e depois da linguagem 'universal' do Classicismo Vienense, e também em geral limitada à música sacra, foi enormemente beneficiada pelas turbulências políticas europeias do começo do séc. XIX. A saída forçada da corte portuguesa da Europa (1808) possibilitou ao Brasil fundar suas próprias instituições, e não muito depois conquistar sua independência política (1822). Importantes artistas, que por razões diversas não podiam ou não desejavam permanecer na Europa, dirigiram-se assim ao Novo Mundo, e entre eles Sigismund von Neukomm (1778-1858), o famoso aluno de Haydn, e o português Marcos Portugal (1762-1830), um compositor de óperas educado na Itália. Através de suas obras e atuação no ensino de música, esses compositores estabeleceram no Brasil (mais precisamente no Rio de Janeiro) dois campos opostos, nos quais se refletia a conhecida dicotomia entre a música instrumental na linha da tradição alemã e a ópera italiana (o "dualismo 
estilístico", ou as "duas culturas", de Beethoven e Rossini (Dahlhaus, 1989, p. 8). Por volta da segunda metade do século, porém, a ópera italiana dominava quase sozinha a cena musical do país; música sinfônica e de câmara, bem como concertos de piano, limitavam-se então a poucas sociedades e associações musicais, enquanto a maioria dos compositores locais assumia o estilo operístico italiano. Para alguns setores do meio musical brasileiro estava colocado, aí, o que passou a ser visto como um problema, e um aparentemente de difícil solução.

Contudo o problema, que se poderia definir (parafraseando Kant) como a 'auto-imposta imaturidade criativa' dos artistas brasileiros, não encontrou a melhor esperada 'solução' primeiramente na música, mas nas letras, onde um problema semelhante - o predomínio do modelo francês - se dava. Tratava-se da ideia de que contribuições da cultura alemã poderiam servir como um meio para a revitalização da cultura brasileira, se não por seus méritos intrínsecos ao menos por suas virtudes, por assim dizer, profiláticas. Muitos anos após o apogeu do germanismo literário e filosófico que encontrou sua melhor expressão na assim chamada 'Escola de Recife' (como o movimento intelectual existente em torno da Faculdade de Direito de Recife ficou conhecido) nas décadas de 1870 e 1880 . Sílvio Romero sintetizou exemplarmente seus pontos de vista. Prefaciando em 1892 os Estudos Alemães (1879) de Tobias Barreto, figura máxima do germanismo no Brasil, Romero declarava aceitar do 'alemanismo' sua 'intuição crítica", na medida em que esta pudesse "revigorar a nossa própria individualidade nacional". Da Alemanha poderiam vir "melhores ideias", que reanimariam a cultura brasileira sem tirar-Ihe "a consciência de seu próprio ser". E finalmente: "a corrente francesa [...] tem sufocado, pela imitação, a individualidade deste povo; o germanismo, que fornece ideias em vez de frases, vivificará a personalidade perdida por meio da crítica de nós mesmos" (apud Martins, 1996, p. 72-73). Não por acaso tal pensamento exerceu um grande influência em Nepomuceno e seu círculo - o compositor havia não apenas vivido em Recife, o centro do movimento, como também teria estudado alemão com o próprio Tobias Barreto. $^{7}$ (A fala de Romero, muito embora possa ser interpretada como uma

7 Comunicação pessoal com o neto do compositor, Sérgio Nepomuceno Alvim Corrêa (novembro de 2008). 
relativização do verdadeiro fanatismo pelas coisas germânicas de Barreto, construída a fim de harmonizar esse fanatismo com sua própria ênfase na cultura como um dos princípios, ao lado de 'meio' e 'raça', a partir dos quais se poderia compreender a formação da nacionalidade brasileira (vide Souza, 2004, p. 19), apreende bem o espírito do germanismo de Nepomuceno, pelo menos daquele que se pode deduzir de suas obras e ações do período em torno de seus anos de estudos na Europa.)

O germanismo serviria portanto a pelo menos dois propósitos vistos por determinados compositores brasileiros como altamente desejáveis: ele forneceria tanto os elementos de uma linguagem musical 'internacional', 'cosmopolita', que possibilitaria a produção de música 'tão boa quanto', isto é, 'o mais similar a' a europeia (a ser compreendida, no campo da música instrumental, como a música do universo austro-germânico), quanto um sistema musical que poderia servir como base que eventualmente poderia levar ao desenvolvimento de uma 'voz nacional', de um estilo musical com cores locais ou identidade étnica. Ambas opções estão ligadas diretamente a duas questões críticas enfrentadas pela geração de Nepomuceno: a necessidade de atualização técnica sentida por esses compositores e a necessidade de afirmar a identidade nacional através da música; ambas questões estavam em jogo, seja quando compositores brasileiros procuravam competir com os compositores da tradição austro-germânica 'em seus próprios termos' (mais próximo do ponto de vista de Barreto), seja quando adotavam suas 'ideias' para uma 'crítica de si mesmos' (mais próximo daquele de Romero). A primeira atitude revela que não devemos igualar a ideia de um 'revigoramento da individualidade nacional' através da adoção de ideias alemães com 'nacionalismo' no sentido que nos acostumamos a ver na expressão no séc. XX. A segunda por sua vez mostra que para muitos compositores, incluindo Nepomuceno e tantos outros em situação semelhante por todo o mundo, parecia claro que, se uma 'escola nacional' dificilmente se desenvolveria da linguagem musical da ópera italiana, não tão improvável seria sua viabilização como, nas palavras de Friedrich Blume, uma "ramificação [Abspaltung] [...] do tronco da música clássico-romântica 
alemã". ${ }^{8}$ Ao contrário da linguagem da ópera italiana, que assim como a literatura francesa se apresentava a esses compositores como objeto a ser imitado (a 'frase pronta'), a música alemã, por se deixar assimilar, fornecendo ao contrário o processo a ser utilizado (a 'ideia' de Romero), poderia servir como fonte de ideias para a criação de uma 'música nacional'. Se compreendermos aqui 'ideias' como 'técnicas' (o que a expressão parece significar de fato, no contexto), torna-se então não mais tão contraditório que a aceitação da influência germânica pudesse ser vista como um dos possíveis caminhos em direção a uma 'arte nacional', ainda mais considerando o fato dela ter sido vista por muitos, à época, como uma forma de escape da hegemonia cultural francesa. Como Wilson Martins notou, trataria-se aí de uma "contradição apenas aparente" (Martins, 1996, p. 522). ${ }^{9}$

Poderíamos sugerir, assim, que o presumido 'epigonismo' dos compositores brasileiros do séc. XIX, pelo menos no que este se relaciona com fontes alemãs no fim do século, refere-se mais a uma recepção da música europeia que Ihes possibilitou tornar-se algo novo, que a 'epigonismo' como frequentemente empregado em relação aos 'pequenos mestres' da música europeia, cujo interesse nessas mesmas fontes se dava com o objetivo oposto, isto é, o de permanecer o mesmo (colocando-se assim conscientemente fora de uma

\footnotetext{
${ }^{8}$ Blume, Friedrich. Romantik. In: Epochen der Musikgeschichte in Einzeldarstellungen, $1974\left[1963^{1}\right]$, p. 372. Muito embora a interpretação de Blume, segundo a qual as assim chamadas 'escolas nacionais' românticas do final do séc. XIX e início do XX nada mais seriam que 'dissidências' da tradição clássico-romântica alemã, seja ainda hoje frequentemente desacreditada em razão das ligações do musicólogo com o regime nazista alemão do período 1933-1945, de onde se deduziria necessariamente seu nacionalismo incondicional e se explicaria sua tentativa de comprovar as origens germânicas das músicas de diversos países europeus (note-se que o mesmo problema ocorre com diversos outros musicógolos alemães atuantes na Alemanha antes e durante a Segunda Guerra Mundial, como Karl Fellerer e Walter Wiora - estes, ao contrário de Blume, filiados ao NSDAP; com maior ou menor justiça, o trabalho desses musicólogos permaneceu inevitavelmente sob suspeição, no período do pós-guerra), nada nos parece indicar, nesse caso particular, que sua análise tenha sido informada mais por esse aspecto de sua biografia que pelo estudo da música mesmo.

9 Segundo Martins, é "1895, e não 1870, o ano triunfal das 'ideias alemãs'; naquele ano, por exemplo, segundo informa Luís Heitor, Leopoldo Miguez viajou pela França, Bélgica, Alemanha e Itália, a fim de visitar os respectivos conservatórios musicais [...] é também em 1895, no mês de julho, que Alberto Nepomuceno regressa de uma viagem de estudos à Europa, passando a lecionar órgão no Instituto Nacional de Música. Ora, é curioso assinalar, numa contradição apenas aparente, que a fecunda atividade de Nepomuceno está identificada com o nacionalismo musical, sobretudo a partir da Série Brasileira, em 1897" (itálicos nossos).
} 
dinâmica inovadora, e dentro da construção de uma tradição conservadora (Röd, 2001, p. 63-80). De acordo com critérios estéticos locais (isto é, brasileiros), a apropriação da música alemã teria de alguma forma se equiparado à busca por 'autenticidade'; segundo critérios europeus, por outro lado, 'epigonismo' contrapunha-se a 'originalidade' (e de acordo com tal julgamento estético até mesmo Mendelssohn, Schumann e Brahms foram descritos como 'epígonos', uma vez que eles claramente se apropriaram do acervo da tradição musical germânica (Wiegandt, 1997, p. 22-23)). Assim a adoção da linguagem musical alemã por compositores brasileiros deve ser compreendida muito mais sob o Begriff de 'transferência cultural' que sob aquele de 'epigonismo'. O fenômeno de um germanismo na história intelectual brasileira, até hoje tratado quase exclusivamente no campo dos estudos literários, é sem dúvida um tema de grande importância para a compreensão da música brasileira do período. E um tema que, ademais, vincula-se a diversos aspectos da música brasileira do séc. XX. ${ }^{10}$

\section{Nepomuceno como Estudo de Caso do 'Germanismo' no Brasil}

Na vida e obra de Nepomuceno os dois núcleos de questões aos quais inicialmente nos referimos se encontram: se sua música é parte da grande quantidade de obras que assumiram a linguagem musical europeia, é igualmente verdade que ela foi também composta num contexto (para não dizer nos limites de um movimento intelectual específico) altamente predisposto e favorável à cultura germânica. Com base nessas duas questões, (a) a relação ainda não inteiramente esclarecida da música brasileira do séc. XIX com a música de compositores europeus, e (b) o fenômeno também pouco estudado (no que toca

\footnotetext{
${ }^{10}$ E inclusive ao desenvolvimento de um nacionalismo musical por Villa-Lobos, sendo um importante exemplo disso sua série de Bachianas Brasileiras, nas quais modelos extraídos da música de Bach constituem o ponto de partida para a composição de uma música que faz um largo uso de elementos folclóricos e populares brasileiros - ao menos como VillaLobos os compreendia. A investigação da 'pré-história' do séc. XX brasileiro mostra que estas obras devem ser também relacionadas a precedentes do séc. XIX, como por exemplo a Ária da Suite Antique de Nepomuceno, uma obra impregnada do Historicismo romântico, e não somente ao contato do compositor com o neo-Classicismo do entre-guerras europeu, durante seu séjour em Paris na década de 20.
} 
seu impacto na música) da influência da cultura alemã na história cultural e intelectual do Brasil, podemos formular a tese inicial de que a música de Nepomuceno pode ser compreendida como um 'estudo de caso' do germanismo no Brasil, não somente pelo que ela própria apresenta, mas também pela afinidade que pode ser percebida entre o pensamento do compositor e o pensamento daquele movimento intelectual. São aspectos concretos de sua biografia, mais que o mero entusiasmo pela cultura germânica que se pode entrever em suas próprias declarações, que fazem possível considerar Nepomuceno uma espécie de contraparte musical do germanismo literário e filosófico da 'Escola de Recife'. Entre esses estão seu contato com figuras de proa desse movimento, o epicentro do germanismo no Brasil; sua atuação como pianista, organista e regente, na qual ao lado de compositores brasileiros encontramos sempre e principalmente compositores alemães (sobretudo Wagner, Beethoven, Mendelssohn, Schumann e Weber); também sua atuação em instituições como o Club Beethoven, dedicado à divulgação da música instrumental de Mozart, Haydn e Beethoven até aquela dos compositores tardios do Classicismo romântico, e o Instituto Nacional de Música, em que Nepomuceno foi professor de piano, órgão e composição (e posteriormente diretor); sua decisão de prosseguir seus estudos em Berlim, que marcou toda sua atuação posterior no Brasil e está diretamente ligada, portanto, a seu esforço por introduzir no Instituto estruturas (como currículos e disciplinas, entre as quais história da música (Castagna, 2007, p. 3) e materiais de ensino (bibliografias, repertórios etc.) típicos do sistema de ensino alemão; e, entre ainda outros possíveis, seu interesse pela música brasileira do passado, que o levou a editar e arranjar obras do Pe. José Maurício Nunes Garcia (1767-1830). ${ }^{11}$

\footnotetext{
${ }^{11} \mathrm{O}$ interesse de Nepomuceno na música de José Maurício deve ser também relacionado ao interesse geral de parte da comunidade musical brasileira (e especificamente carioca) em vincular a música brasileira à música alemã, num processo no qual, como apontou Paulo Castagna, coube um papel de destaque a Alfredo d'Escragnolle Taunay (o Visconde de Taunay). Segundo Castagna, o "Visconde de Taunay, essencialmente ligado à elite e interessado em encontrar no Brasil obras, autores e atividade musical que pudessem ser inseridas na tradição europeia de composição e cuja qualidade estivesse em pé de igualdade com os exemplos europeus [...] [ocupou-se] da 'redescoberta' da música de José Maurício e das providências para salvar seus manuscritos, para imprimir e executar o que for possível. Taunay tinha uma forte motivação para isso. Em suas cartas refere-se à filiação de José Maurício à estética alemã, [...] movimento ao qual aderiram, no Brasil, já na década de 1890. Alberto Nepomuceno e [...] outros. Na carta de 10 de junho de 1898, por exemplo, Taunay é explícito ao se referir à 'máscula e gloriosa escola alemã a que se filiara [Nunes Garcia] e que tanto destoava das
} 
Especialmente relevantes para a pesquisa sobre Nepomuceno são seus anos de estudo em Berlim e sua música instrumental do período (para piano, quarteto de cordas e orquestra). Os fatos básicos de seus estudos na Akademie der Künste (então 'Königliche' Akademie der Künste) e no Stern'sches Konservatorium nos mostram com que pessoas e fontes o compositor esteve em contato e que repertório ele ouviu, tocou, regeu e compôs. Ao menos se considerarmos as "duas formas básicas de recepção" (Dannuser, 1991, p. 166) da música descritas por Hermann Danuser - a forma interpretativa/performática, na qual o receptor figura como 'leitor' ou executante, e a forma auditiva, em que ele toma parte como ouvinte - tais perguntas são de grande interesse, nos fornecendo insights de sua recepção da música alemã que podem ser relacionados a suas composições. Testemunhos de seu interesse pela literatura teórica alemã são, por um lado, suas doações para a biblioteca do Instituto Nacional de Música do Rio de Janeiro e, por outro, suas traduções para o português de textos de autores como Bellerman (Der Contrapunkt, que está ligado aos estudos na Akademie der Künste [Wiechert, 1997, p. 80]) e Schoenberg (o início do Harmonielehre). Como vemos, a pesquisa da experiência alemã de Nepomuceno, uma tarefa até hoje incompleta, oferece bases sobre as quais toda a vida posterior do compositor pode ser estudada.

\section{Nepomuceno, o Romantismo Alemão e Brahms}

A contextualização histórica do estilo musical de Nepomuceno centrada no tema de suas influências europeias tem sido um tópico recorrente na literatura, muito embora por vezes tratado de modo quase intuitivo. De tal extração são as menções aos "aspectos do vigor estrutural de Brahms" percebidos por certo crítico na Sinfonia em sol menor, ou às "buscas harmônicas de tendência germânica que se sente em algumas de suas obras" (Neves, 1981, p. 21), por outro. Essas duas citações ilustram, muito claramente, casos em que o problema é corretamente enunciado, sem ser contudo desenvolvido ou mesmo perseguido. De fato, as obras de Nepomuceno, e especialmente as de seu período de estudos na 
Alemanha, indicam uma recepção da tradição musical austro-germânica ainda pouco estudada. ${ }^{12}$ Acreditamos que a razão para a existência dessa lacuna (e aqui poderíamos entrever uma prolongação do ponto de vista modernista nos dias de hoje) seja o fato da ligação de Nepomuceno com modelos europeus da segunda metade do séc. XIX ter sido até hoje geralmente tratada como um aspecto menos louvável de sua obra. Em lugar de uma abordagem abrangente, que considere as diversas faces da obra Nepomuceno, prevalece uma predileção por seus aspectos mais claramente ligados ao nacionalismo (e, por esta razão, supostamente progressistas), e para cada página dedicada ao seu papel no desenvolvimento de uma 'música brasileira' (sempre na acepção que o séc. XX daria a tal expressão), poucas linhas se prestam a lembrar que "outras obras de Nepomuceno mostram menor preocupação com a nacionalização da criação musical" (Neves, 1981, p. 21). Por outro lado, o mesmo tratamento desigual pode ser verificado dentro mesmo do âmbito do estudo de seus modelos europeus: se satisfaz a muitos identificar a influência de compositores como Grieg, que colocam o brasileiro Nepomuceno a par da vanguarda nacionalista de seu tempo (muito embora, como veremos, a formação germânica de Grieg e sua duradoura marca na linguagem musical do norueguês constituam elas mesmas um capítulo à parte na pesquisa sobre o compositor, e um que torna necessário determinar mais precisa e cuidadosamente onde residiria seu 'vanguardismo'), com muito menos entusiasmo é reconhecida a influência de compositores considerados conservadores, como Brahms, o mestre das 'formas antigas', como Wagner o teria definido, em certa ocasião. Não obstante ter sido Nepomuceno um dos compositores brasileiros mais atentos aos desenvolvimentos técnicos e novidades estéticas de seu tempo, como nos atesta o uso que fez da escala de tons inteiros (utilizada principalmente por compositores russos do séc. XIX, como Glinka e Dargomïzhsky, e depois pelos impressionistas franceses), de modos nativos brasileiros (isto é, presentes na música folclórica do país), dos ritmos e formas de música popular urbana

\footnotetext{
12 O que levou a uma série de visões conflitantes acerca dessa recepção. Comentando sobre o tema, Dudeque sugeriu que "[...] a crença geral de que Nepomuceno foi influenciado principalmente pela música de Wagner pode ser errônea, uma vez que a influência de conceitos derivados e observados na música de Brahms é notória na obra aqui analisada [o Quarteto de cordas n. 3]" (Dudeque, 2005, p. 211).
} 
brasileira (carioca, de fato), entre tantos outros exemplos, resta o fato de apenas uma pequena parte de sua obra ter sido condicionada por tais elementos. Naturalmente a grande parte restante de sua produção não deve ser ignorada, se desejarmos compreender sua produção mais completamente. (Nepomuceno não foi exceção à regra e esteve sujeito ao mesmo dualismo de tradição/inovação que marcou diversos outros compositores de sua geração, que é a mesma de Schoenberg. Na segunda metade do séc. XIX, essa dicotomia estaria diretamente relacionada à divisão entre música instrumental na linha de desenvolvimento de Brahms e música dramática na linha de Wagner.)

A discussão acima ilustra bem a dicotomia entre 'universalismo', como poderíamos chamar a prática comum da música europeia (Bispo, 1991), ${ }^{13}$ e 'nacionalismo', a utilização de elementos musicais nacionais, não-europeus, observada na pesquisa da obra de Nepomuceno. Muito embora a enunciação dessa dualidade frequentemente venha acompanhada da ideia de que Nepomuceno foi um dos primeiros compositores brasileiros a promover uma fusão desses elementos, essa interpretação não foi até hoje associada à análise da música, que poderia apontar como essa síntese teria se dado. Como propusemos em outra ocasião, ${ }^{14}$ contudo, preciso seria falar de uma justaposição desses elementos, mais que de uma síntese: duas de suas obras para piano mais brahmsianas (como comumente apontado na literatura), a Sonata op. 9 de 1893 e

\footnotetext{
${ }^{13}$ Lembremo-nos que a linguagem musical 'universal', o sustentáculo da prática comum do Romantismo, é a linguagem da música alemã do final do séc. XVIII e princípio do XIX, e ainda, como comentou Blume, "com sotaque vienense" (Blume, Friedrich, 1974 [1963ㄹ] p. 371 (Romantik). É, portanto, a linguagem da música instrumental austro-germânica da linha de Haydn. Mozart e Beethoven, cuja elevação invocada na historiografia tradicional, de idioma local a linguagem 'universal', é explicada por um lado pelo impacto, influência, longevidade e difusão internacional de estilo (todos esses elementos beneficiados, é justo lembrar, pelo progressivo esmaecimento da música instrumental da Itália e França na segunda metade do séc. XVIII), e por outro por duas noções cultivadas na literatura: a ideia de um estilo universal em seus fundamentos (isto é, compreensível por toda e qualquer cultura), e a sugestão de um “'universalismo' de um ideal a ele imanente” (Bispo, Antonio A., O 'Ano Mozart' e o Brasil, 1991).

${ }^{14}$ Vidal, João Vicente, Nepomuceno e Brahms: Análise Comparativa de suas Variacões op. 28 e 35, 2001. Aqui procuramos identificar de uma forma mais precisa as relações estilísticas entre os dois compositores, como uma primeira tarefa na consideração do tema da relação de Nepomuceno com suas influências europeias. A partir da proposição de que Nepomuceno tomou a obra de Brahms como um modelo para a sua primeira série de variações para piano solo, acreditamos ter obtido respostas parciais para algumas das perguntas suscitadas pela discussão em torno das influências europeias de Nepomuceno.
} 
as Variações sobre um Tema Original op. 28 de 1901, são alternadas por duas de suas obras mais claramente ligada ao que Goldberg chamou de "ideal nacionalista" (Goldberg, 2001, p. 1), o Batuque de 1888 (posteriormente orquestrado e inserido na Série Brasileira) e a Galhofeira op. 13 n. 4 de 1894. A literatura tem sido prolífica em apontar quais obras de Nepomuceno seriam representativas do nacionalismo musical: exemplos desse 'ideal' (Béhague, 1979 . p. 28-39), segundo Béhague, seriam o Quarteto de Cordas n. 3 (postumamente alcunhado 'Brasileiro'), a Série Brasileira, o Garatuja e as peças para piano Galhofeira e Brasileira, lista à qual Corrêa acrescentou posteriormente as Valsas Humorísticas op. 22 n. 2 e 4 (apud Goldberg, 2001, p. 82). Que 'ideais' estariam em questão nas muitas outras obras de Nepomuceno, contudo, ainda resta para ser mais claramente definido.

Um primeiro passo nessa direção seria, acreditamos, o exame do que tem sido apontado como a influência de Brahms, ou 'tendência germânica', em Nepomuceno a partir do estudo de sua música instrumental, dos seus anos de formação na Europa mas também dos anos imediatamente posteriores. A principal questão que se coloca aí, sem dúvida, é determinar se o estilo de Nepomuceno, nessa parte específica de sua produção, corresponderia a um estilo geral, ou seja, a uma prática comum, do Romantismo alemão, ou se estaríamos frente a traços estilísticos condicionados/determinados pela recepção da música de um compositor específico (Brahms, no caso) ou, por outra, de uma 'escola' a ele associada. O problema, já complexo, é feito ainda mais difícil por Brahms ter se tornado, nas últimas décadas do séc. XIX, um modelo onipresente o bastante para tornar confusas as fronteiras separando a linguagem musical geral da época (se é que se pode falar de uma, em período tão diversificado - nos referimos aqui, em todo caso, à linguagem geral do campo da música germânica 'absoluta') de um estilo, mais específico, relacionável à música de Brahms e seu impacto em compositores coevos - estilo ao qual Max Reger em 1894 se referiu poeticamente como "a bruma de Brahms" (Reger, 1928, p. 39-40). A dificuldade é bem ilustrada, por exemplo, no comentário de Anthony Pople sobre Grieg e (o compositor inglês Charles Villiers) Stanford, 
cujos estilos musicais podem ter parecido a gerações posteriores como amplamente similar àquele de Brahms em diversos aspectos, deveria ser na verdade compreendido de modo bastante diverso em termos de linguagem musical. Em termos de estilo, o idioma musical essencial deles era de fato um tipo de idioma austro-germânico genérico [general-purpose], como seria adequado da formação de ambos [nota: "Grieg estudou no conservatório de Leipzig a partir de 1858 e Stanford nos conservatórios de Leipzig e Berlim na década de 1870"], mas para além dele ambos acrescentaram elementos que deram a suas linguagens musicais uma identidade local (Pople, 2001, p. 602).

No entanto a interpretação de Pople, bastante apropriada em sua conclusão (que pouco difere da interpretação anterior de Blume para as 'escolas nacionais' românticas europeias), não oferece explicação para a questão que nos interessa, que é por que razão, e de que forma, tal 'idioma austro-germânico genérico' pôde parecer a gerações posteriores similar ao estilo de Brahms. A matéria relaciona-se, naturalmente, aos motivos que fizeram de Brahms um modelo tão importante para certos círculos de compositores da segunda metade do séc. XIX, um tópico que tem atraído considerável atenção de parte da pesquisa sobre o compositor alemão. Parte da resposta é encontrada no fato de Brahms ter apresentado, através de sua longa carreira artística (cobrindo um período de cerca de 43 anos - de 1853 a 1896 - da primeira à última obra publicada, e nela todos principais os gêneros musicais exceto a ópera), um estilo relativamente estável, isto é, uma obra sem mudanças radicais de direção como as observáveis em Beethoven e Liszt, entre uma série de outros exemplos. Outra razão é o fato de ele ter optado (e desenvolvido de modo consistente e bem-sucedido) por um estilo compreendido à época como 'conservador', num momento em que a linguagem musical ocidental começava a ter suas premissas e fundamentos desafiados por transformações sucedendo-se em passos cada vez menores (como pelo cromatismo cada vez mais ubíquo no fim do século, em um processo que eventualmente levaria às experiências pós-tonais do início do séc. XX e depois). Sobretudo por esta razão, Brahms significou para uma legião de compositores da geração de Nepomuceno - de Zemlinsky, Reger e Schoenberg a Busoni, Hindemith e Weill, na esfera dos territórios de língua alemã, e ainda Fauré, Taneyev, Elgar e Vaughan Williams, fora deles - um porto seguro de tradição e estabilidade tonal, um afluxo que fez com que o estilo de Brahms - as 
formulações individuais de sua 'fala' - fosse pouco a pouco elevado quase à condição de escola ou tradição - isto é, à condição de um sistema coletivo, de uma 'língua' compartilhada (um processo que evoca, inevitavelmente, a dualidade saussuriana de langue/parole).

As considerações acima nos levam a estabelecer como objetivo principal de nossa pesquisa, da qual, cumpre reiterar, apenas uma pequena fração pode ser aqui exposta, analisar o que tem sido genericamente apontado como a 'tendência germânica' da obra de Nepomuceno a partir da hipótese de que trataria-se, no que se refere à música instrumental dos seus anos de formação na Europa e seguintes, não somente da absorção de fontes musicais da tradição clássicoromântica germânica (o 'idioma genérico' de Pople), mas também (como frequentemente invocado na literatura sobre o compositor) da recepção da música de Brahms, em particular. Recepção que teria sido, por sua vez, possibilitada tanto por seu contato com o que já foi definido como o "círculo dos conservadores acadêmicos de Berlim", como apontado por Dudeque, quanto por um contato direto com a obra do compositor alemão; Heinrich von Herzogenberg (18431900), um dos mais destacados compositores desse círculo e, como já dito, professor de composição de Nepomuceno na Akademie der Künste de Berlim, não por acaso tinha em Brahms não apenas um amigo, mas também um influente 'role-model'. O indicador biográfico, contudo, não deve ser visto aqui como mais que um ponto de partida para o exame do problema proposto, que é compreender como a aproximação de Nepomuceno desse academicismo germânico' em seus anos de formação, bem como a presumida influência de Brahms, teriam se refletido em atitudes suas em relação a forma musical, desenvolvimento motívico/temático, contraponto e linguagem harmônica (parâmetros que naturalmente se oferecem como eixos orientadores de qualquer análise que se tente da obra do compositor). 


\section{A Música Brasileira do Séc. XIX e Nepomuceno: Perspectivas Metodológicas}

\section{Recepção e Intertextualidade}

Especialmente face às duas principais lacunas da história da música brasileira do séc. XIX, o estabelecimento de seu(s) contexto(s) e a análise de suas obras, pode-se dizer que a pesquisa pode tirar grande proveito de uma dupla perspectiva de história 'contextual' e 'composicional', e especificamente das perspectivas dos conceitos de 'história da recepção' e de 'intertextualidade', ambos originários dos estudos literários. 'História da recepção' trata das "sequências, interrelações e conflitos no contexto histórico" (nos quais o compositor figura ou como ouvinte, leitor ou executante, isto é, como receptor - o 'nível estésico', em linguagem semiótica -, ou como criador, isto é, através de uma 'recepção composicional' - o 'nível poiético'); 'intertextualidade', por sua vez, "analisa e compara estruturas de textos" (Stauffacher, 2002, p. 215) (isto é, o estudo do nível 'imanente', ou 'neutro', da obra). O estudo da recepção, que procede, como notou Dahlhaus, "reconstruindo as categorias e opiniões dos ouvintes contemporâneos" (Dahlhaus, 1983, p. 153), se baseia no reconhecimento de que essas (categorias e opiniões - ideias, em suma) são essencialmente construções dependentes de tempo, lugar e sociedade particulares, e assim contigentes, mais que 'verdades' duradouras sobre a obra de arte; por outro lado, procede de modo diverso um estudo da recepção composicional que toma forma da análise de 'relações de intertextualidade', compreendendo a obra em primeiro lugar não em sua vinculação com o ambiente à sua volta, mas em sua vinculação com outras obras. A combinação de ambas abordagens constituiria, portanto, uma 'dupla raiz', histórica e estilística, para a história da música brasileira do séc. XIX.

Um fato indisputado da história da música é o fenômeno segundo o qual composições musicais do presente se relacionam com aquelas do passado, seja ele próximo ou distante. Esta relação, que dá corpo ao continuum histórico que nos permite falar de história dos gêneros e de períodos histórico-musicais (como Barroco, Classicismo etc.), é frequentemente explicada, quando o tema é não a 
transformação gradual dos estilos musicais através dos tempos, mas sim a ocorrência de tal conexão na obra de um compositor particular, e especificamente no caso em que essa ligação nos remete ao seu contexto histórico imediato, através do ubíquo conceito de influência. No entanto, e por conferir um papel eminentemente passivo para aquele que a 'sofre' (quando via de regra o oposto é verdadeiro, tendo o compositor um papel ativo na escolha de seus modelos), por um lado, e por minimizar o papel de respostas coletivas - "intersubjetivas", nas palavras de Samson ${ }^{15}$ - a determinados repertórios e em momentos históricos específicos, por outro, o conceito passou nas últimas décadas a ser cada vez mais descrito como um instrumento excessivamente vago para a descrição do processo de rapport ao passado a que nos referimos. Para as generalizações derivadas do estudo de tais respostas coletivas, de grupos de ouvintes específicos (que podem ser delimitados, por exemplo, por nacionalidade, classe social, profissão etc.), ganhou ampla circulação na musicologia o conceito de recepção; para a abordagem das relações concretas observáveis entre obras musicais, por outro lado, e mais recentemente, o de intertextualidade. ${ }^{16}$

O conceito de recepção, tomado da pesquisa desenvolvida a partir do final da década de 1960, especialmente por Hans Robert Jauß e a assim chamada 'Escola de Konstanz', postulava “compreender a história da literatura e das artes [...] como um processo de comunicação estética, no qual estão divididas igualmente as três instâncias de autor, obra e receptor (leitor, ouvinte e observador, crítico e público)", para assim "restituir o receptor como destinatário e mediador, e consequentemente como condutor de toda cultura estética, em seu direito histórico" (Jauß, 1992, p. 996). A ideia central do paradigma de Jauß é que a obra de arte, qualquer que seja seu gênero ou material, não é um objeto

\footnotetext{
${ }^{15}$ Samson, Jim. Reception, in: NGDMM2, 2001.

16 Ludwig Finscher comentou que "[...] o conceito de intertextualidade poderia ser completamente proveitoso para a Musicologia, precisamente para caracterizar e tornar mais preciso o espaço das relações concretas entre uma obra e outra do campo largamente descrito com o conceito de influência", acrescentando, ainda, que "a intertextualidade como categoria tem a grande vantagem de ser mais precisa que a categoria geral da influência, na medida em que ela dá conta das relações concretas, audíveis e observáveis, entre uma obra ou texto e outra independentemente de influências gerais de estilos de época, gênero ou individuais, e no entanto em todo seu espectro de relações abertas e ocultas. Além disso ela é mais objetiva, uma vez que evita as conotações de juízo de valor do conceito [de 'influência']" (Finscher, 1998, p. 101, 103).
} 
que permanece inalterável ou auto-suficiente ao longo do tempo, mas inversamente um objeto cujo significado se revela num processo baseado na interação de ocorrências de efeito e recepção, sendo condicionado assim pelas condições históricas existentes por trás das diversas interpretações dadas a uma obra (uma concepção diretamente relacionada à ideia de opera aperta de Umberto Eco). O 'momento na história' passa então a ser mais importante que o conceito monolítico de 'obra', e a história do objeto artístico a ser considerada sob dois pontos de vista: aquele que enfatiza o objeto que deflagra tal 'processo de comunicação estética' - a história do efeito (ou impacto) da obra ('Wirkungsgeschichte'), e o que enfatiza o público para o qual o processo é direcionado - a história da recepção da obra ('Rezeptionsgeschichte').

A premissa dos estudos de recepção, de que, como Samson colocou, “existem certos fatores estabilizantes (mentalités) que influenciam as respostas de comunidades culturais particulares, estabelecendo os limites dentro dos quais os atos individuais de percepção se dão" (Samson, 2001) (uma premissa que parece mais esclarecer as condições em que uma 'influência' ocorreria que dispensar completamente a ideia), traz para a discussão dois elementos adicionais: (a) a

114 ideia de um 'horizonte de expectativas': o conhecimento prévio do ouvinte, contra o qual a obra é recebida; e (b) aquilo que Meyer chamou de 'limitações do estilo': o "conjunto de limites que estabelece um repertório de alternativas do qual escolher, dado algum contexto composicional específico”, que por sua vez é “aprendido por compositores e intérpretes, críticos e ouvintes” (Meyer, 1996, p. 7 e 10). Tais elementos tornam-se especialmente importantes, quando falamos de “recepção como praticada por compositores" (Dahlhaus, 1983, p. 151), ou seja, não de respostas coletivas, mas inversamente de respostas individuais à música desse grupo específico de ouvintes. Knapp analisou a tensão existente entre esses elementos - o 'horizonte de expectativas' do público e as 'limitações do estilo' dentro das quais o compositor se move - e como ela levou compositores como Brahms a buscar em suas composições um equilíbrio entre semelhança com obras de seus predecessores, que favoreceria sua recepção, e inovação, que garantiria por sua vez seu status de original (Knapp, 1998, p. 1-30). Esta tensão permaneceu uma questão geral do Romantismo, e muito embora a categoria da originalidade 
seja inegavelmente um dos mais importantes dogmas artísticos do Romantismo do séc. XIX, a emulação de obras pregressas, "a força vital da tradição musical”, segundo Peter Burkholder, permaneceu sendo prática corrente, e "o tratamento das mesmas questões musicais de uma maneira nova e original poderia permitir a um jovem compositor atingir o nível de seus predecessores". ${ }^{17}$

Quanto a como as 'mentalidades' das quais fala Samson incidem na recepção composicional, um exemplo esclarecedor pode ser encontrada na recepção composicional da obra de Brahms no ambiente em que Nepomuceno estudou durante seus anos na Alemanha. Sabidamente a atmosfera reinante nos conservatórios austríacos e alemães do final do séc. XIX abriu caminho para uma recepção entusiástica da música do compositor alemão, uma vez que neste ambiente uma mentalidade voltada ao cultivo da tradição - um poderoso fator estabilizante - exercia forte força. E às reações coletivas deste grupo de ouvintes específico, constituído essencialmente de compositores e que pode ser reconhecido até meados do séc. XX (Burkholder, 1984, p. 75-83), seguiram-se as manifestações individuais de seus participantes - e de tal forma, que a pretensão de que o estudo da recepção composicional de um compositor deva considerar em primeiro lugar precisamente a 'mentalidade' subliminar em jogo dificilmente pode ser ignorada. "A atitude enraizada na tradição da Akademie der Künste de Berlim deu ao movimento contra o 'progresso', contra Wagner e a Neudeutsche Schule de Weimar, o nome de academicismo [Akademismus]" (Fellerer, 1976, p. 8), diagnosticou Fellerer em seu estudo sobre o meio em que muitos dos 'seguidores' de Brahms podem ser encontrados. Schenk, por sua vez, definiu 'academicismo' não apenas como um conceito que remete a uma direção estilística identificada com o Classicismo (também presente no Romantismo alemão na forma do assim chamado 'Classicismo romântico'), mas também como

17 Burkholder, Peter. Intertextuality, in: NGDMM2, 2001. A crescente demanda por originalidade artística, que se fez sentir sobretudo a partir da segunda metade do séc. XVIII, iria inevitavelmente chocar-se com a visão de mundo cujo postulado principal era um tipo de comércio de ideias que resultava, via de regra, no compartilhamento dos vernáculos musicais hoje chamados de estilos de uma época ou lugar. A história do conceito de originalidade é o lento e inexorável movimento em direção a estilos musicais em que a 'expressão dos sentimentos' fosse central, do empfindsamer Stil de meados do séc. XVIII, passando pelo movimento Sturm und Drang (considerado hoje uma das fases iniciais do Classicismo) por volta de 1770 até, finalmente, o Romantismo do séc. XIX. 
um conceito que descreve também uma estrutura institucional e um programa político-cultural. ${ }^{18} \mathrm{O}$ 'epigonismo' dos compositores 'acadêmicos', assim, deve ser compreendido como uma manifestação peculiar de recepção composicional, condicionada pela mentalidade claramente tradicionalista desses compositores.

A perspectiva da intertextualidade, por sua vez, baseia-se na ideia de que a literatura (e, por semelhança, a música) refere-se essencialmente a si mesma. Cunhado por Julia Kristeva em seu Semeiotike: Recherches pour une Sémanalyse (1969), o conceito tem como fundamento a ideia de que nenhum texto é inteiramente original e único, mas inevitavelmente uma teia de referências e citações (voluntárias ou não) a outros textos. Essa teia, segundo Kristeva, condiciona em grande medida a forma e o(s) significado(s) atribuídos pelo leitor ao texto. "Textos são 'intertextuais'; eles se referem não ao mundo em geral, mas a outros textos" (Taruskin, 1993, p. 114), assim sintetizou Taruskin a visão da intertextualidade - Bloom, por sua vez, foi de opinião ainda mais drástica: "textos não existem [...] mas apenas relações entre textos" (Bloom, 1975, p. 3). Com propriedade Stauffacher definiu ambos pontos de vista - 'história da recepção' e 'intertextualidade' - como “duas perspectivas básicas e intimamente intricadas do 116 fenômeno literário", que se relacionam "de forma semelhante a diacronia [se referindo ao que se dá através do tempo] e sincronia [se referindo ao que se dá no mesmo tempo, mas também atemporalmente]" (Stauffacher, 2002, p. 215). Seria no entanto falso dizer que a ação teórica da intertextualidades e coloca indiferente à história. Muito ao contrário, a consciência histórica tem nela um papel importante, por exemplo, quando se fala de "relações monodirecionais" - o empréstimo numa peça de elementos de uma segunda - e "relações mútuas" 19 - o uso, por dois ou mais compositores de uma mesma época, das mesmas convenções musicais -, ou quando se fala de "relações de criação de formas

\footnotetext{
18 Segundo Schenk, "o atributo acadêmico sublinha o momento do escolástico, ao qual todo Classicismo tende. Assim acadêmico deve ser compreendido, em relação à Berliner Hochschule, não apenas como conceito estilístico. Ele remete a uma estrutura institucional, à uma afiliação organizacional tanto quanto a um programa de política cultural. A Königliche [Real], e depois: Staatliche [Estatal] akademische Hochschule für Musik era um estabelecimento educacional [Lehranstalt] dentro da Akademie der Künste. Sua atitude estética marcou no séc. XIX o conceito do Acadêmico na música alemã, sobre Berlim para além da cidade" (Schenk, 2004, p. 11).

${ }_{19}$ Burkholder, Peter. Intertextuality, in: NGDMM2, 2001.
} 
musicais, circunstâncias biográficas ou institucionais etc. para a apreciação comparativa" (Brügge, 1996, p. 1). Aplicado ao estudo da música, onde o conceito passou a ser reconhecido pela musicologia como um eficiente instrumento de análise estilística, a ideia de intertextualidade possibilita tratar das relações entre textos musicais de uma forma mais abrangente que a simples noção de 'empréstimo'. Como notou Burkholder, a perspectiva da intertextualidade englobaria todo o espectro de formas através das quais uma obra musical referese a ou baseia-se em outras obras, do fenômeno local da citação direta à modalidades mais gerais, como alusão estilística e o uso de convenções.

Especialmente quando nos voltamos para a música dos compositores do séc. XIX ditos 'acadêmicos' na forma de indagações sobre quanto de sua prática se relaciona ao que Ihes foi apresentado em instituições de ensino (seja na forma de instrução formal ou de conhecimento que disponíveis em livros teóricos e didáticos) ou sobre quanto de sua prática teria derivado do estudo e emulação de obras de compositores consagrados, isto é, na forma de indagações sobre se a prática de tais compositores tinha como referência mais convenções e regras gerais de composição do que obras individuais tidas como clássicos de um determinado gênero (ou estilo, meio etc.) ou vice-versa, estamos diante de questões que impõe o reconhecimento de um diálogo entre textos. (E mesmo a discussão em torno da categoria essencialmente romântica do 'gênio' depende de tal reconhecimento, ao menos se o definirmos, com Branda Lacerda, como "o artista dotado de força criadora, espontânea e primitivamente original (ao contrário daqueles que dependiam dos processos acadêmicos de elaboração do texto poético)", caracterizado pela "negligência ao respeito a regras" (Branda Lacerda, 2008, p. 6).

Pascall referiu-se a esse diálogo intertextual como a 'dimensão referencial' de toda obra musical - o domínio de sua gênese e contexto histórico, que existe ao lado de sua 'dimensão estrutural' - o domínio de sua estrutura individual (Pascall, 1983, p. vii). Muito embora a 'vida pregressa' de uma obra (sua dimensão referencial) seja frequentemente encarada como uma questão relacionada mais à biografia e contexto histórico do compositor (e assim ao domínio dos estudos da recepção), é inegável que sua revelação quase sempre traz ao debate informações cruciais para a compreensão de sua 'dimensão 
estrutural' (ao domínio dos estudos das relações de intertextualidade). Pode-se tratar da Sonata op. 35 (para violoncelo a piano) de Brahms sem se fazer menção ao fato da obra ter sido composta a partir do modelo oferecido por uma sonata para a mesma formação e na mesma tonalidade de mi menor (e curiosamente também de mesmo número de opus) do hoje pouco conhecido violoncelista alemão Bernhard Romberg (1767-1841), e fazendo uso, ainda, de elementos emprestados da Arte da Fuga de Bach, do Konzertstück op. 92 de Schumann, do terceiro movimento da Sonata Op. 143/D. 784 de Schubert e do primeiro movimento da Sonata op. 2 n. 3 de Beethoven, mas reconhecer e analisar o uso de tais fontes sem dúvida abre novos horizontes ao pesquisador (ainda que desnudar a 'teia intertextual' que pode-se extrair de cada obra pareça por vezes com 'um passeio num labirinto', para tomar emprestada expressão de Dahlhaus (1987, p. 85). Não se trata, porém, da comparação de obras frequentemente observada na antiga prática musicológica, voltada primariamente aos propósitos de uma historiografia da proveniência, mas sim da ênfase, na confrontação de contextos musicais distintos, na elucidação de diferenças estéticas. A mudança de métodos e propósitos foi sintetizada por Brügge, segundo quem

o outrora estático ponto de vista 'a obra A influencia a obra B' capitulou em favor da variável metáfora da 'intertextualidade' [...] de forma que na exposição de cada elemento musical comum (na forma de similaridades da estética formal) a divergência da concepção (na forma de dissimilaridades da estética do conteúdo) é trazida claramente à tona (Brügge, 1996, p. 1).

O conceito de intertextualidade apresenta-se como um instrumento teórico de alta relevância para uma revisão da música brasileira do séc. XIX e suas vinculações com a música europeia do período que adote como ponto de partida métodos de análise estilística. No modelo que o conceito propõe, a noção de influência estilística se manifesta não no sentido dialético de confrontação de vozes, mas numa concepção dialógica onde tais vozes se apresentam justapostas, aglutinadas ou transformadas. Tal noção, de um 'entrelaçamento de vozes' numa obra musical, nos ajuda talvez a compreender sutil porém expressiva diferença entre imitatio, a mera utilização do vernáculo musical (a linguagem musical 
compartilhada), da qual tanto dependeram o Barroco e o Classicismo, e æmulatio, a tomada consciente de um determinado estilo ou obra por um compositor com o propósito de emular ou suplantar a referência, atitude amplamente disseminada no Romantismo (Dahlhaus, 1989, p. 27).

No entanto um estudo que pretenda abordar a 'dimensão referencial' da música de Nepomuceno, mas que o faça somente para se limitar à mera coleção de possíveis coincidências (intencionais ou não) de fragmentos rítmicos e melódicos, progressões harmônicas, texturas e figuras de acompanhamento etc., não poderia ir além de evidenciar o que seria para muitos óbvio, pouco acrescentando assim à melhor compreensão da obra do compositor. Ao contrário, é somente na medida que esses elementos, as 'vozes' de suas fontes, são articulados em análises da "dimensão estrutural" da obra original de Nepomuceno que a possibilidade de colocá-las a serviço de uma pesquisa histórico-musical relevante se viabiliza. Desprovido da análise musical, ademais, o esforço de apontar as relações estilísticas ou temáticas entre as obras de Nepomuceno e aquelas de outros compositores do séc. XIX redundaria num exercício estéril, incapaz de determinar o que e em que medida Nepomuceno acrescentou de original ao legado de que buscou se apropriar em seu período de formação. Trata-se aí de constatar a existência de contribuições merecedoras de nota na música do compositor, mais que angariar prestígio às custas de reivindicações de originalidade.

Quanto ao papel dominante desempenhado por Brahms no campo de relações estabelecido por Nepomuceno com suas fontes musicais, devemos tomálo como no sentido popperiano de uma pregnant hypothesis, analisando sua música não com base na hipótese de que ele teria sofrido essa influência na totalidade de suas obras, mas sim na de que, em grande parte dos casos, a langue do 'Classicismo romântico' de Brahms está presente, como uma reserva de técnicas e procedimentos composicionais. Se a análise de estratégias e escolhas composicionais particulares pode nos revelar algo sobre as crenças e atitudes, estéticas e teóricas, de um compositor, é na música de Nepomuceno que pode ser encontrada a palavra final sobre sua personalidade artística. 


\section{Considerações sobre Análise Estilística}

Naturalmente a sugestão de que Nepomuceno concebeu muitas de suas obras ou segundo modelos brahmsianos ou em linguagem musical contendo elementos estilísticos desse compositor - uma sugestão que se apoia em estudos preliminares, e que pode portanto figurar aqui como uma tese preliminar - deve ser investigada dos mais variados possíveis pontos de vista e através de exemplos que confirmem ou não a hipótese. A perspectiva analítica desempenha aí, portanto, um papel fundamental (a não ser que se deseje fundamentar interpretações "mais com associações biográficas que com fatos composicionais" (Dahlhaus, 1989, p. 257). A hipótese não sugere, contudo, que todas as obras de Nepomuceno possam ser relacionadas a obras específicas de Brahms, e, muito menos, que o compositor alemão tenha exercido sobre o brasileiro uma ascendência total e monopolizadora, mas sim que formas, gêneros e técnicas composicionais tradicionalmente associadas na literatura a Brahms lhe foram importantes em seus anos de formação e depois. O estudo da questão implica, consequentemente, uma análise estilística e comparativa de exemplos da música de Nepomuceno e de compositores do Romantismo alemão ou a ele associados.

Quanto à indagação sobre o que seria, no panorama da música germânica do final do séc. XIX (considerando aí também música não-alemã, mas diretamente dela derivada), brahmsiano, que também não wagneriano, tchaikovskiano ou franckiano, trata-se de uma questão que nos força necessariamente a refletir sobre como os conceitos de recepção e intertextualidade incidem na prática da análise musical, e especialmente no sentido de uma análise estilística. Convém portanto delinear uma metodologia que torne possível uma definição precisa da procedência das 'qualidades gerais' da obra de Nepomuceno (ou, a esse respeito, de qualquer outro compositor), mais que sua simples descrição. Inicialmente, duas possibilidades se apresentam: procurar por processos composicionais específicos (o que Schoenberg chamou de 'ideia' - as “verdadeiras ideias características”), ou por traços genéricos da obra musical (seu 'estilo', segundo Schoenberg - os aspectos externos de uma 'ideia' essencial chamados por ele de seus "sintomas") (Schoenberg, 1975, p 178). (Leonard Meyer elaboraria a distinção também como 
"estilo [manner]" e "substância [matter]") (Meyer, 1996, p, 6-7). Essas duas formas distintas de abordar a questão fariam referência, portanto, a (a) traços típicos do estilo, sejam eles (a.1) os encontrados em suas características exteriores, como as descritas a propósito do estilo de Brahms por Walter Niemann - "[...] os movimentos por terças e sextas, seus dobramentos orquestrais, sua preferência por espaçamentos amplos e por um registro grave sonoro e escuro, [e] a voluntariosa linguagem rítmica, com sua tendência por construções sincopadas e em tercinas de todos os tipos" (Niemann, 1912, p. 39) - ou por Grout \& Palisca - "sonoridades cheias; figuração em acordes quebrados; frequente dobramento da linha melódica em oitavas, terças ou sextas; múltiplas appoggiaturas de caráter cordal; [...] freqüente uso de ritmos cruzados [...] [e] desenvolvimento de ideias simples em texturas inovadoras" (Burkholder, 2009, p. 733) - ou sejam eles (a.2) processos composicionais considerados paradigmáticos de um determinado compositor ou período: seus "artifícios técnicos e expressivos mais sutis (as 'ideias')" - em outras palavras, através da busca e compilação de 'universais' para a música desse compositor ou período (embora seja problemático compreender tais processos abstratamente e associá-los e um único compositor, há casos em que se pode apontar técnicas que associam-se a determinados compositores como elementos definidores de suas linguagens musicais - como por exemplo o procedimento de 'variações progressivas' a Brahms). Mas uma análise pode também apontar para obras, e não somente para características e processos, a fim de possibilitar uma comparação significativa das relações de intertextualidade existem entre duas ou mais obras. Trataria-se aí, portanto, de $(b)$ a referência direta a passagens, movimentos ou obras inteiras, na medida em que essas possam ou devam ser evocadas no âmbito de uma análise comparativa. Em outras palavras, da referência a 'particulares' - (novamente invocando Saussure,) expressões da parole do compositor - que podem invocar a condição de representativos de um estilo, tradição ou escola - uma langue musical - na medida em que são, também, manifestações locais de seus (do estilo, tradição ou escola) 'universais'.

Já a oportunidade com que uma 'análise estilística' preocupada com a consideração de fenômenos de recepção e intertextualidade fará uso de uma ou outra abordagem ('a' ou 'b'), depende mais do próprio objeto de estudo que da 
decisão arbitrária do analista. Exemplos disso, na obra de Nepomuceno, são as 3 Folhas d'Álbum (uma tradução da forma consagrada alemã 'Albumblätter') e as Variações em lá menor de Nepomuceno, que se relacionam com obras específicas de Brahms, a Balada op. 10 n. 4 e as Variações sobre um tema de Paganini op. 35, por um lado, e a Sinfonia em sol menor, em que só se pode perceber similaridades genéricas, relacionadas ao idioma sinfônico austro-germânico do final do séc. XIX, por outro. Robert Hatten sugeriu a esse respeito uma proveitosa diferenciação entre 'intertextualidade estilística' e 'intertextualidade estratégica', a primeira descrevendo referências a convenções de estilos ou tradições musicais, a segunda de relações entre obras específicas (Hatten, 1985). As peças para piano de Nepumuceno mencionadas seriam são exemplos de uma 'intertextualidade estratégica', e nesse sentido também 'música sobre música': música que "adquire sua concepção de uma reelaboração de música já dada e previamente existente" (Danuser, 1996, p. 54). Quanto à Sinfonia em sol menor, poderia-se falar inversamente de uma 'intertextualidade estilística'. Ambas formas de análise estilística não são, no entanto, livres de riscos. Tanto pode a referência reiterada a um constructo abstrato (como ocorre em 'a') diluir-se na falta de matéria concreta

122 para comparação, quanto pode nossa compilação de tais 'universais' refletir mais nossa própria recepção contemporânea da música estudada, aquilo que nos interessa nela hoje, que aquela de seus contemporâneos (o que seria adverso ao próprio fundamento da estética da recepção). Por outro lado, a repetida tomada de exemplos musicais concretos e específicos (como em ' $b$ ') pode levar a formas veladas de determinismo ("A causa B, e não poderia ser diferente") ou reducionismo ("B pode ser completamente explicado por referência a A"), limitando assim a capacidade crítica da análise. Por tais razões, será proveitoso uma abordagem que contemple as duas formas, com atenção ao fato de que a 'intertextualidade' na música frequentemente descreve mais a (re)utilização de ideias e procedimentos composicionais nos níveis menores do motivo e da frase (onde se encontram unidades de "certa completude", para usar novamente a linguagem schoenberguiana) (Schoenberg, 1967, p. 3) que ao 'diálogo' entre grandes seções ou obras inteiras. A 'voz' do compositor se evidencia mais frequente e claramente nessas unidades menores, e por mais que a arquitetura 
geral de uma obra, seu aspecto formal, possa ser também reutilizada, permanece o fato do estilo musical existir inteiramente nos menores níveis estruturais da música: seus motivos e frases.

A tentativa de compreender os 'artifícios técnicos e expressivos mais sutis' das obras musicais deve ser tomada portanto, nesse contexto, fundamentalmente como 'análise da(s) ideia(s)'. Ainda que a visão do problema contida no trabalho de Schoenberg pareça não resolver de modo total a questão da análise estilística (e precisamente em razão da alta medida de subjetivismo envolvida na diferenciação entre 'sintomas' e 'ideias' de uma obra), sua demanda pelo estudo da essência, do momento individualizador da obra musical, de grande importância para o desenvolvimento desta forma de análise, se presta como um promissor ponto de partida para a apreciação da música de Nepomuceno.

\section{Breve Estudo de Caso: As 3 Folhas d'Álbum de Nepomuceno e a Balada op. 10, n. 4 de Brahms}

Uma comparação entre duas obras já citadas, as 3 Folhas d'Álbum de Nepomuceno e a Balada op. 10 n. 4 de Brahms, fornece um exemplo do tipo de análise que acreditamos ser de interesse para a pesquisa da música brasileira do séc. XIX. Novamente em razão dos limites de espaço, procuramos não mais que esboçar o tipo de cotejo entre obras que poderá, não em todos os casos, mas ainda assim em muitos deles, auxiliar a tarefa de mensurar a natureza e extensão da influência de Brahms sobre Nepomuceno. O pequeno grupo de peças foi composto por Nepomuceno em seu primeiro semestre como aluno de composição da Akademie der Künste de Berlim (semestre de verão de 1891), publicado no final de 1891 no Brasil como as três primeiras de uma série de 'seis peças para piano' (das quais as últimas três se perderam) e estreada em 1892 em Kristiania (hoje Oslo, Noruega) por sua futura mulher Walborg Bang, uma aluna de Theodor Leschetizkys em Viena. (O próximo contato de Walborg com seu conterrâneo Grieg seria, posteriormente, de grande importância para Nepomuceno.) Ao que parece a obra também foi executada depois pelo próprio Leschetizky em Viena, muito 
embora não se tenha até hoje podido esclarecer suficientemente as circunstâncias exatas do evento (Alvim Corrêa, 1996, p. 41). Uma comparação entre as três peças de Nepomuceno e as três principais seções da Balada op. 10 n. 4 de Brahms revela similaridades e características comuns que nos levam à hipótese de que Nepomuceno pode ter usado a obra do compositor alemão como um modelo composicional. De fato sabemos, através de relatos de seus alunos, que a emulação deliberada de uma obra ou de um grupo de obras era parte fundamental do método de ensino de composição de Herzogenberg, como já mencionado um de seus professores em Berlim; Ethel Smyth, uma aluna inglesa de Herzogenberg, relatou, por exemplo, que entre seus exercícios para Herzogenberg contavam-se " 'invenções' a duas vozes no estilo de Bach" (Wiechert, 1997, p. 79). Tal hipótese sugere, assim, que as três seções principais

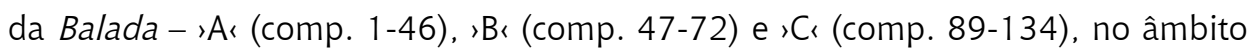
de uma construção em cincos partes `A-B-A'-C-B'ı - forneceram elementos para a composição das três peças de Nepomuceno. Discorremos a seguir, portanto, sobre os pontos de contato que se pode estabelecer entre as obras.

\section{Folha d'Álbum n. 1}

Como pontos de semelhança mais facilmente detectáveis, ocorrem na primeira Folha d'Álbum de Nepomuceno tanto a forma estrófica com reexposição (uma 'Reprisenbarform') levemente variada (ıa-a-b-a'‘) da seção 'A textura (melodia, arpejos descendentes e baixo) da Balada de Brahms (Exemplo 1.1). Ao lado de tais características, incapazes por si de denunciar uma relação entre os dois compositores, visto que ocorrem com grande frequência na literatura para piano do séc. XIX, certos gestos melódicos da Balada são reproduzidos por Nepomuceno de modo quase literal, eventos que podem ser tomados, inversamente, como indícios de relações musicais mais profundas entre as obras (Exemplo 1.2). 
Exemplo 1.1a: Balada op. 10, n. 4, comp. 1-4

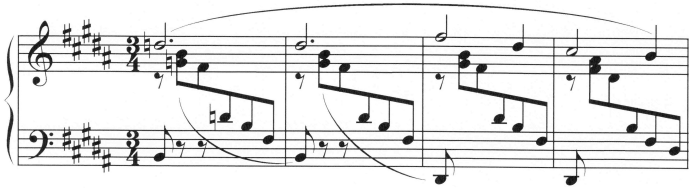

Exemplo 1.1b: Folha d'Álbum n. 1, comp. 1-2

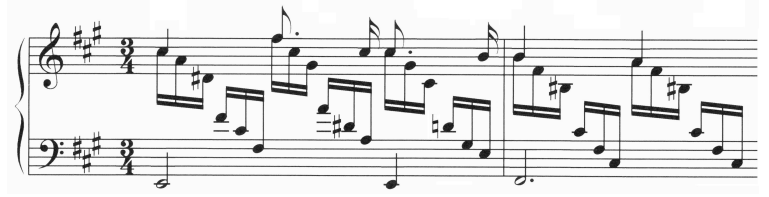

Exemplo 1.2a: Balada op. 10 n. 4, comp. 36-37

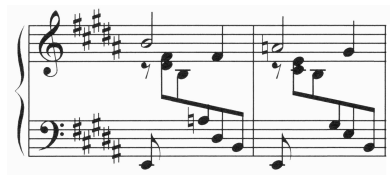

Exemplo 1.2b: Folha d'Álbum n. 1, comp. 5-6

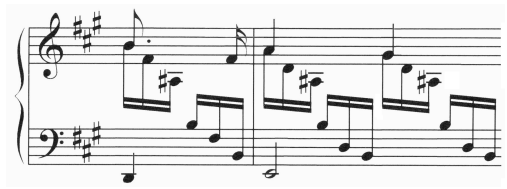

As relações às quais nos referimos, estando para além dos pontos de contato reconhecíveis na concepção formal e textura da primeira Folha d'Álbum, e ainda em momentos de 'quase-citação' como o destacado acima, podem ser identificados nas marcas estilísticas da harmonia e da melodia. Se considerarmos como a principal característica da ideia básica da Balada op. 10 n. 4 de Brahms (o que Schoenberg chamaria de sua 'Grundgestalt') a contraposição das tonalidades de si menor e si maior de seus primeiros dois compassos (Exemplo 1.1), tornada ainda mais evidente pela ocorrência dos sextos graus de ambas escalas, sol natural e sol sustenido (ambiguidade tonal presente também na peça anterior do ciclo, a Balada op. 10 n. 3, 'Intermezzo'), concluiremos necessariamente que trata-se aí de 
um artifício visando não estabelecer claramente a tonalidade da obra em seu início. Uma intenção semelhante pode ser observada também nos dois primeiros compassos da Folha d'Álbum n. 1 de Nepomuceno, englobando basicamente uma cadência interrompida (ou 'de engano') construída a partir de uma estrutura de dupla dominante (sobre a própria dominante: Exemplo 2.1). Contudo essa intenção (de não estabelecer claramente a tonalidade da obra em seus primeiros compassos) é realizada por Nepomuceno de modo diverso ao de Brahms: apesar de fundamentada na dualidade maior/menor, a primeira frase (comp. 1-4) da Balada de Brahms permanece na tônica; a Grundgestalt de Nepomuceno (comp. 1-2), ao contrário, move-se prontamente, reproduzindo a dualidade brahmsiana 'si menor/si maior' como 'lá maior/fá sustenido menor' (de onde o 'engano' da cadência: o acorde de sétima da dominante sobre 'mi' gera a expectativa de resolução no primeiro, e não no segundo acorde). A construção da ideia básica da peça de Nepomuceno não é, contudo, uma reformulação gratuita do observado no início da Balada de Brahms; ao contrário, ela serve principalmente a um outro propósito, que relaciona-se também a um traço muito particular da peça do compositor alemão. Este é o procedimento de fazer não coincidirem, na 126 recapitulação variada da primeira seção saı - isto é, 'a'ı - resolução melódica e resolução harmônica. Se em Brahms a primeira, a volta variada da primeira frase, ocorre pontualmente no compasso 27, a segunda é postergada, mediante a prolongação da dominante pelo baixo, até dois compassos depois (Exemplo 2.2a); de modo similar em Nepomuceno, a recapitulação da seção rar vem como esperado no compasso 27, mas a resolução harmônica (a cadência interrompida contida exatamente na Grundgestalt da peça) somente um compasso depois (Exemplo 2.2b). (Note-se que o obscurecimento dos limites entre desenvolvimento, e mais especificamente do que é comumente referido como 'retransição', e recapitulação, nas formas-sonata clássicas tradicionalmente marcadas pelo retorno simultâneo do primeiro tema e da tônica no início da recapitulação, se tornaria uma marca do estilo de Brahms (vide Smith, 1994, p. 237261), e uma certamente já bastante familiar de qualquer compositor trabalhando em sua 'esfera de influência' no final do século.) 
Exemplo 2.1: Folha d'Álbum n. 1, comp. 1-2 (redução)

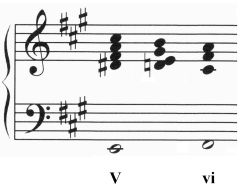

Exemplo 2.2a: Balada op. 10 n. 4, comp. 26-29

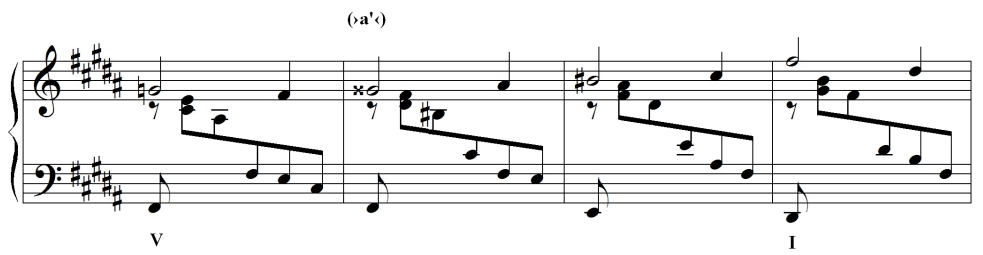

Exemplo 2.2b: Folha d'Álbum n. 1, comp. 26-28

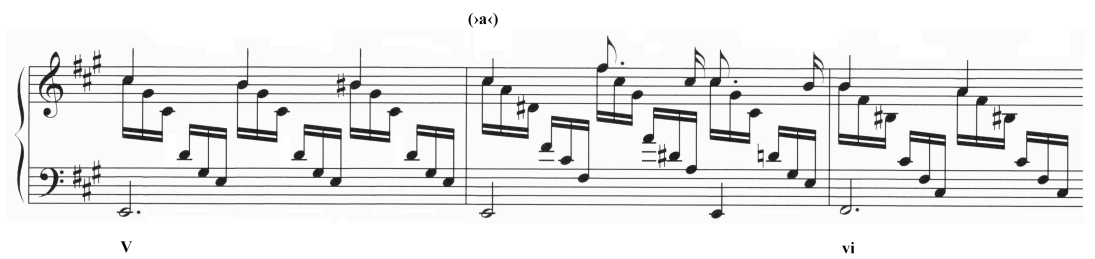

Quanto a trabalho motívico, um revelador ponto de contato entre a linguagem musical de Nepomuceno e aquela de Brahms pode ser observado quando se confrontam as melodias de ambas as peças despidas de appoggiaturas, notas de passagem e antecipações, em suma, de seus 'embelezamentos' no nível da superfície melódica. Assim reduzidas, os motivos melódicos essenciais de ambas as peças podem ser claramente observadas: nos dois casos, conformações de quatro notas (Exemplo 3.1b e 3.2b, comparar com 3.1a e 3.2a, respectivamente) organizadas segundo uma sequência de intervalos relativamente estável ('segunda/terça/quinta' em Brahms, 'quarta/quinta/segunda' em Nepomuceno). Mas novamente surgem, da utilização de um princípio comum, diferenças marcantes em sua realização: se em Brahms o motivo básico é repetido ou variado de modo a mantê-lo mais ou menos inalterado em sua essência ( $c f$. comp. 1-16), em Nepomuceno ele é prontamente desenvolvido, através da retrógrada do motivo na sequência imediata da melodia (segunda/quinta/quarta), 
por um lado, e de uma reprodução variada (por meio da aumentação rítmica) dessa retrógrada no baixo, por outro (Exemplo 3.2c). Trata-se aí, claramente, da “construção de um tema [...] através da contínua modificação dos componentes intervalares e/ou motívicos da ideia inicial [...] [na qual] os intervalos são 'desenvolvidos' através de procedimentos como inversão e combinação, os ritmos através de artifícios como aumentação e deslocamento", isto é, do uso da técnica de 'variação em desenvolvimento', como concebida por Schoenberg e descrita por Frisch em seu importante estudo sobre o compositor alemão (Frisch, 1984, p. 9).

Exemplo 3.1a: Balada op. 10 n. 4, comp. 1-8

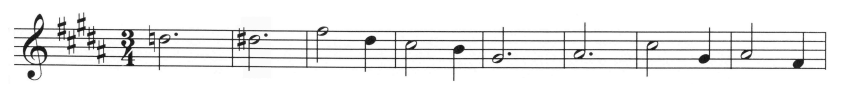

Exemplo 3.1b: Balada op. 10 n. 4, comp. 1-8 (redução)

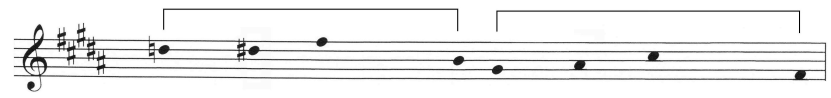

Exemplo 3.2a: Folha d'Álbum n. 1, comp. 1-4

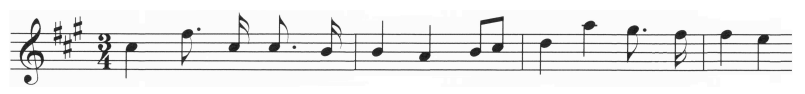

Exemplo 3.2b: Folha d'Álbum n. 1, comp. 1-4 (redução)

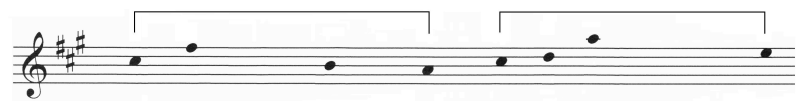

Exemplo 3.2c: Folha d'Álbum n. 1, comp. 1-4 (redução: soprano e baixo)

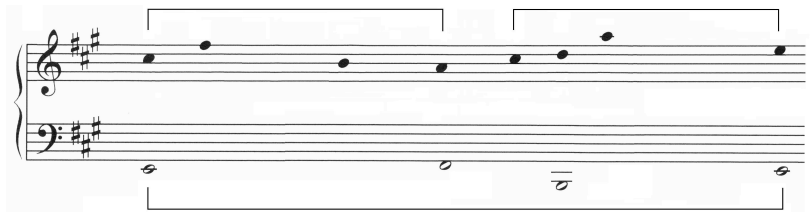




\section{Folhas d'Álbum n. 2 e 3}

Assim como ocorre na primeira peça do pequeno grupo, a segunda Folha d'Álbum de Nepomuceno pode ser relacionada à Balada de Brahms tanto em alguns de seus aspectos 'exteriores' quanto em certos procedimentos composicionais menos evidentes. Inicialmente, observa-se a utilização por Nepomuceno, na primeira parte ( $\mathrm{A}$ r - subdividida como ra-b-a's - de uma construção `A-B-A-Codaı) da peça em questão, de uma textura em três vozes bastante similar àquela da seção `Bı (também estruturada como ıa-b-a’ı) da Balada de Brahms (Exemplos 4a e b). Como indícios de que não se trataria aí (e, novamente, como no caso da primeira Folha d'Álbum) da mera utilização de uma fórmula genérica do repertório romântico poderíamos enumerar, contudo, a importância atribuída às vozes internas (os polegares de ambas mãos na Balada, a voz do tenor na Folha d'Álbum) nas seções ıb das duas peças (cf. comp. 55-57 da primeira e 13-16 da segunda); a polirritmia encontrada em ambas (quiálteras de três notas contra duas concheias regulares em Brahms, quiálteras de duas notas contra três colcheias regulares, em Nepomuceno); e, mais importante, o movimento paralelo em sextas e décimas (= terças), que dá corpo a um modelo contrapontístico em duas vozes (cf. Exemplo 5b).

Exemplo 4a: Balada op. 10 N. ${ }^{\circ}$, comp. 47-48

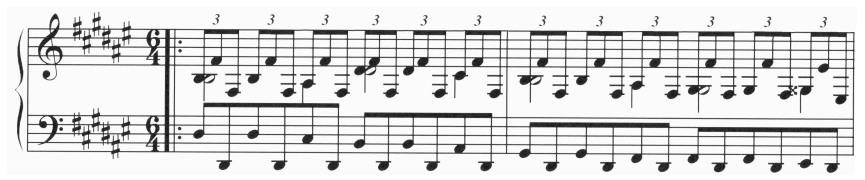

Exemplo 4b: Folha d'Álbum n. 2, comp. 1-4

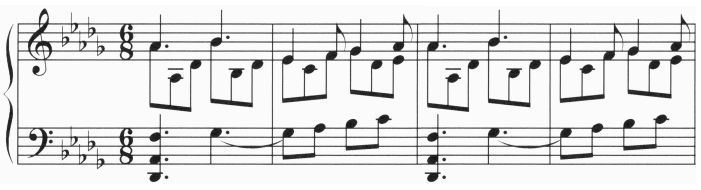

Já na terceira Folha d'Álbum de Nepomuceno, uma pouco comum variedade de forma estrófica invertida ('Gegenbarform'), ’A-B-B'، (onde a seção `A 


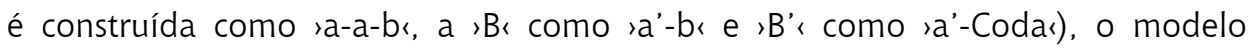
contrapontístico em duas vozes de Brahms (Exemplo 5b, comparar com Exemplo 4a), é usado de forma ainda mais evidente. Aqui, contudo, não apenas as vozes (baixo e do soprano) do modelo são invertidas (Exemplo 5c, comparar com Exemplo 5b), como também são realizadas assincronicamente, de acordo com o conhecido procedimento brahmsiano de 'dissonância métrica', segundo o qual dois níveis rítmicos conflitantes são estabelecidos: no caso, a voz superior em compasso 3/4 e o baixo em compasso 6/8; como vemos, essa configuração rítmica é tornada aqui ainda mais complexa, uma vez Nepomuceno também desloca a voz inferior em uma colcheia (Exemplo 5a).

Exemplo 5a: Folha d'Álbum n. 3, comp. 1-4

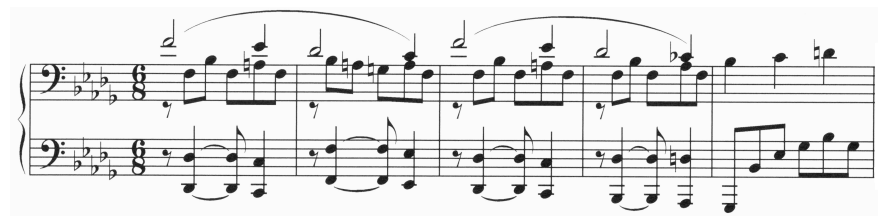

Exemplo 5b: Balada op. 10 n. 4, comp. 47-50 (redução)

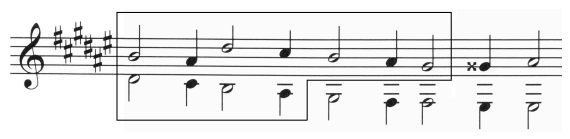

Exemplo 5c: Folha d'Álbum n. 3, comp. 1-5 (redução)

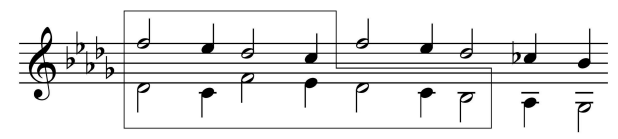

Em outros aspectos, a terceira Folha d'Álbum relaciona-se também à seção ,C da Balada de Brahms: por um lado no movimento na região média do piano, e por outro na concepção rítmica e melódica similar das passagens, que, como ocorrido na primeira Folha d'Álbum, pode ser descrita como uma 'quase citação' de Brahms (Exemplo 6, a e b). 
Exemplo 6a: Balada op. 10 n. 4, comp. 89-93 (redução)

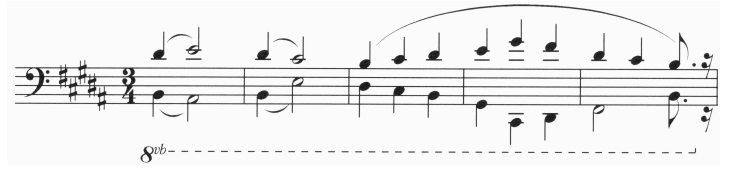

Exemplo 6b: Folha d'Álbum n. 3, comp. 1-8 (redução)

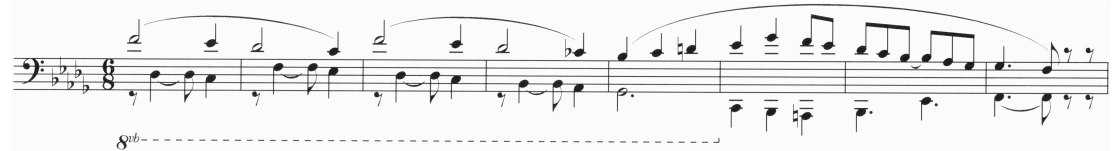

$* * *$

O exemplo das 3 Folhas d'Álbum para piano de Nepomuceno, que poderíamos confortavelmente descrever como um exercício de composição do primeiro ano de estudos do compositor, apontam para o campo rico e ainda pouco explorado das relações de intertextualidade decorrentes da recepção de Brahms por Nepomuceno durante sua estada em Berlim. Se por um lado essas pequenas peças nos revelam que não se trata aqui simplesmente do empréstimo de formas e texturas de obras de Brahms, ou de meras citações ou referências claramente identificáveis pelo ouvinte (da época ou dos dias atuais), mas sobretudo da identificação e apropriação, por Nepomuceno, de soluções de Brahms para problemas relacionados, entre outros temas, à apresentação e desenvolvimento de ideias musicais, a momentos críticos como os de transição e recapitulação, mesmo em obras de pequena escala, e, ainda, a como criar e explorar construções polifônicas como elementos estruturadores dentro de texturas homofônicas, por outro elas nos permitem supor que a análise e emulação de obras de Brahms tinham seu lugar no método de ensino de seus professores de composição em Berlim. Portanto mais importante que a identificação de analogias na 'superfície' das obras de Brahms e Nepomuceno será a descoberta de relações mais profundas, que se tornam visíveis somente através da apreciação dos procedimentos composicionais do primeiro (como dito texturas, formas, harmonia e trabalho temático-motívico etc.) e das formas com que eles são utilizados ou reelaborados pelo segundo. Pois dessa forma é possível reconhecer a origem (ou ao menos casos precedentes) de técnicas musicais 
específicas, e relacionar entre si obras que, 'externamente', isto é, à primeira vista, podem não parecer especialmente semelhantes. Muitos dos elementos levantados por essa linha de pesquisa da música de Nepomuceno nos fazem crer que seu manuseio do repertório de técnicas composicionais preponderantemente germânicas pode ser considerado resultado de seu contato com a vida musical alemã e com os acadêmicos de Berlim, e que muito embora este repertório não Ihe fosse inteiramente desconhecido já antes de sua chegada à Alemanha, somente ali the foi verdadeiramente 'esclarecido', no sentido de uma explicação hermenêutica, isto é, interpretativa. Daí portanto a vinculação histórica de uma investigação de outra forma puramente musical.

\section{Referências}

ALVIM CORRÊA, Sérgio Nepomuceno. Alberto Nepomuceno: Catálogo Geral. Rio de Janeiro: Funarte, 1996.

ANDRADE, Mário de. Ensaio sobre a Música Brasileira. São Paulo: Martins Fontes, INL/MEC, 1972.

BÉHAGUE, Gerard. The Beginnings of Musical Nationalism in Brazil. Austin: 132 University of Texas, 1971.

. Music in Latin America: an Introduction. Englewood Cliffs, N.J., 1979.

BISPO, Alexandre A.. O século XIX na Pesquisa Histórico-Musical Brasileira: Necessidade de sua Reconsideração. Latin American Music Review, v. 2, n.1, p. 130-142, 1981.

BLOOM, Harold. A Map of Misreading. Oxford: Oxford University Press, 1975.

BLUME, Friedrich (Ed.). Epochen der Musikgeschichte in Einzeldarstellungen (excertos da $1^{\text {a }}$ Edição da Die Musik in Geschichte und Gegenwart). Kassel: Bärenreiter e Munique: DTV (Deutscher Taschenbuch-Verlag), 1974.

BOZARTH, George S. (Ed.). Brahms Studies: Analytical and Historical Perspectives. Nova Iorque: Oxford University Press, 1990.

BRANDA LACERDA, Marcos. Aspectos do Romantismo na Música. São Paulo: 2008 (ensaio não-publicado).

BRÜGGE, Joachim. Intertextualität als Problem: zum Finale von Mozarts D-DurQuintett, KV 593, und 'Jupitersymphonie', KV 551 iv. Acta Musicologica, v. 68, fasc. 1, p. 1-11, 1996.

BURKHOLDER, J. Peter: Brahms and Twentieth-Century Classical Music.19thCentury Music, v. 8, n. 1, p. 75-83, 1984. 
BURKHOLDER, J. Peter; Grout, Donald Jay \& Palisca, Claude. A History of Western Music. New York: W. W. Norton, 2009.

CASTAGNA, Paulo. Um Século de Musica Brasileira. Pesquisa referente ao Triênio 2004-2006. UNESP, Instituto de Artes, 2007.

CURT LANGE, Francisco. A Música no Brasil durante o Século XIX (Regência Império - República). In: Günther, Rober. Die Musikkulturen Lateinamerikas im 19. Jahrhundert: Tendenzen und Perspektiven (Studien zur Musikgeschichte des 19. Jahrhunderts). Regensburg: Gustav Boose, 1982, p. 121-166.

DAHLHAUS, Carl. Nineteenth-Century Music. Berkeley, Los Angeles: University of California Press, 1989.

. Schoenberg and the New Music, Cambridge: Cambridge University Press, 1987.

. Foundations of Music History. Cambridge: Cambridge University Press, 1983.

DANUSER, Hermann. Zur Interdependenz von Interpretation und Rezeption in der Musik. In: DANUSER, Hermann; KRUMMACHER, Friedhelm (Ed.). Rezeptionsästhetik und Rezeptionsgeschichte in der Musikwissenschaft (Publikationen der Hochschule für Musik und Theater Hannover 3), 1991, p. 165-177.

. Hommage-Komposition als 'Musik über Musik'. In: WAGNER, Günther (Ed.). Jahrbuch des Staatlichen Instituts für Musikforschung Preußischer Kulturbesitz, 1996, p. 54.

DUDEQUE, Norton. Aspectos do Academicismo Germânico no Primeiro Movimento do Quarteto n. 3 de Alberto Nepomuceno. Ictus 6, p. 211-232, 2005.

FELLERER, Karl G. Der Akademismus in der deutschen Musik des 19. Jahrhunderts. Opladen: Westdeutscher, 1976.

FINSCHER, Ludwig. Intertextualität in der Musikgeschichte. In: DANUSER, Hermann; PLEBUCH, Tobias (Ed.). Musik als Text. Bericht über den Internationalen Kongreß der Gesellschaft für Musikforschung, Freiburg im Breisgau 1993. v. 1. Kassel: Bärenreiter, 1998, p. 50-53.

FRISCH, Walter. The Early Works of Arnold Schoenberg, 1893-1908. Berkeley e Los Angeles: University of California Press, 1993.

. The Brahms 'Fog': On Analyzing Brahmsian Influence at the Fin de Siècle. In: Frisch, Walter (Ed.). Brahms and His World. Princeton: Princeton University Press, 1990, p. 81-99.

. Brahms and the Principle of Developing Variation. Berkeley: University of California Press, 1984.

.Programa dos Kasseler Musiktage 1976 do Internationaler Arbeitskreis für Musik, p. 6.

GUANABARINO, Oscar. Artes e Artistas [in: O País, 19 de outubro de 1895]. In: Pereira, Avelino Romero. Música, Sociedade e Política: Alberto Nepomuceno e a República Musical, 2007. 
GOLDBERG, Luiz Guilherme D. As Variações sobre um Tema Original op. 29 de Alberto Nepomuceno. Revista do Conservatório de Música da Universidade Federal de Pelotas, v. 1, n. 1, 2001.

Alberto Nepomuceno e a Missa de Santa Cecília de José Maurício Nunes Garcia. In: Castagna, Paulo (Ed.). Anais do VI Encontro de Musicologia Histórica, 2004, p. 146-172.

GROUT, Donald J.; Palisca, Claude V. História da Música Ocidental. Lisboa: Gradiva, 1997.

HATTEN, Robert S. The Place of Intertextuality in Music Studies. American Journal of Semiotics, v. 3, n. 4, p. 69-82, 1985.

JAUSS, Hans R. Rezeption, Rezeptionsästhetik, 1992, p. 996 [in KROPFINGER, Klaus: Rezeptionsforschung] In: Die Musik in Geschichte und Gegenwart. Allgemeine Enzyklopädie der Musik, 2. ed. p. 200-201, 1998.

KNAPP, Raymond. Brahms and the Anxiety of Allusion. Journal of Musicological Research, v. 18, n. 1, p. 1-30, 1998.

KRISTEVA, Julia. Bakhtin, le Mot, le Dialogue et le Roman. In: KRISTEVA, Julia. Sēmeiōtikē: Recherches pour une Sémanalyse, 1969.

MAGALDI, Cristina. Music in Imperial Rio de Janeiro. Oxford: The Scare Crow Press, 2004.

MARTINS, Wilson. História da Inteligência Brasileira, 1877-1896. São Paulo: T. A. Queiroz, 1996. v. IV.

MEYER, Leonard B. Style and Music: Theory, History, and Ideology. Chicago: University of Chicago Press, 1989.

MILHAUD, Darius. Brésil. La Revue Musicale v. 1, p. 60-61, 1920.

MONTEIRO, Eduardo. Henrique Oswald (1852-1931). Un Compositeur Brésilien au-delà du Nationalisme Musical; L'Exemple de sa Musique de Chambre avec Piano. Tese de Doutorado. Université Paris IV, Sorbonne, 2000.

MOURA, Rogério Soares de. Recompondo o Passado: Alberto Nepomuceno sob a Batuta Modernista, 2008.

NEVES, José Maria. Música Contemporânea Brasileira, São Paulo: Novas Metas, 1981. NIEMANN, Walter. Moderne Klaviermusik in Portugal. Die Musik, v. 14, part 3, p. 271-273, 1915.

Johannes Brahms und die neuere Klaviermusik. Die Musik, v. 12, part 1, 1912.

ORREGO-SALAS, Juan. Brazil. In: Apel, Willi (Ed.). Harvard Dictionary of Music, 1969, p. 111.

PASCALL, Robert: Brahms: Biographical, Documentary and Analytical Studies. Cambridge: Cambridge University Press, 1983.

PEREIRA, Avelino Romero. Música, sociedade e política: Alberto Nepomuceno e a República Musical. Rio de Janeiro: Universidade Federal do Rio de Janeiro, 2007. 
POPLE, Anthony. Styles and Languages Around the Turn of the Century. In: Samson, Jim (Ed.). The Cambridge History of Nineteenth-Century Music. Cambridge: Cambridge University Press, 2001. p. 601-620,

REGER, Max. Briefe eines deutschen Meisters. Leipzig: Koehler \& Amelang, 1928. RÖD, Wolfgang: Tradition und Innovation in der Sicht der Philosophie. In: Gruber, Gernot (Ed.). Die Kammermusik von Johannes Brahms. Tradition und Innovation. Laaber: Laaber-Verlag 2001. p. 63-80.

SAMSON, Jim (Ed.). The Cambridge History of Nineteenth-Century Music. Cambridge: Cambridge University Press, 2001.

. Rewriting Nineteenth-Century Music History. In: Contemporary Trends in Musicology and Ethnomusicology (X IRAM Conference, Skopje), 2005 (Disponível em:<http://www.mmc.edu.mk/IRAM/Conferences/Contemporary/Trendshttp://www. mmc.edu.mk/IRAM/Conferences/ContemporaryTrendsIVJSamson.pdf $>$. Acesso em: novembro de 2008.

SCHENK, Dietmar. Die Hochschule für Musik zu Berlin: Preußens Konservatorium zwischen romantischem Klassizismus und Neuer Musik, 1869-1932/33. Wiesbaden: Franz Steiner, 2004.

SCHOENBERG, Arnold. Fundamentals of Musical Composition. London: Faber, 1967.

SCHOENBERG, Arnold: Why no Great American Music? (1934). In: Style and Idea. STEIN, Leonard (Ed.), 1975.

SMITH, Peter H. Liquidation, Augmentation, and Brahms's Recapitulatory Overlaps. 19th-Century Music, v. 17, n. 3, p. 237-261, 1994.

SOUZA, Ricardo Luiz de. Método, Raça e Identidade Nacional em Sílvio Romero. Revista de História Regional v. 9, n. 30, 2004.

STAUFFACHER, Werner: Intertextualität und Rezeptionsgeschichte bei Alfred Döblin: 'Goethe dämmerte mir sehr spät'. Intertextualität: Zeitschrift für Semiotik, v. 24, n. 2-3, 2002.

THE NEW GROVE Dictionary of Music and Musicians (NGDMM2). Stanley Sadie/John Tyrrell (Eds.). London: MacMillan Press LTD., 2001.

TARUSKIN, Richard. Revising Revision: Review of Korsyn and Strauss. Journal of the American Musicological Society, v. 46, n. 1, 1993.

WELCKER, Felix. Kritik. Die Musik, v. 9, part 4, p. 381-383,1910.

WIECHERT, Bernd. Heinrich von Herzogenberg: Studien zu Leben und Werk. Göttingen: Vandenhoeck \& Ruprecht, 1997.

WIEGANDT, Mattias. Vergessene Symphonik? Studien zu Joachim Raff, Carl Reinecke und zum Problem der Epigonalität in der Musik. Sinzig: Studiopunkt Verlag, 1997.

E-mail: joaovicentevidal@gmail.com

Artigo recebido e aprovado em 25 de outubro de 2010 